\title{
Tabularia
}

Sources écrites des mondes normands médiévaux Vivre des deux côtés de la Manche ( $\mathrm{X}^{\mathrm{e}}-\mathrm{XIII}{ }^{\mathrm{e}}$ siècle) I 2011

\section{Cross-Channel communication and the end of the 'Anglo-Norman realm': Robert fitzWalter and the Valognes inheritance}

La communication de part et d'autre de la Manche et la fin du "royaume anglonormand »: Robert fils-Gautier et l'héritage de Valognes

Daniel Power

\section{OpenEdition}

Journals

\section{Electronic version}

URL: http://journals.openedition.org/tabularia/1452

DOI: $10.4000 /$ tabularia. 1452

ISSN: $1630-7364$

Publisher:

CRAHAM - Centre Michel de Boüard, Presses universitaires de Caen

\section{Electronic reference}

Daniel Power, « Cross-Channel communication and the end of the 'Anglo-Norman realm': Robert

fitzWalter and the Valognes inheritance », Tabularia [Online], Vivre des deux côtés de la Manche (Xe-XIII

e siècle), Online since 28 April 2011, connection on 30 April 2019. URL : http://

journals.openedition.org/tabularia/1452; DOI : 10.4000/tabularia.1452 


\title{
Cross-Channel communication and the end of the 'Anglo-Norman realm': Robert fitzWalter and the Valognes inheritance ${ }^{1}$
}

\section{La communication de part et d'autre de la Manche et la fin $d u$ "royaume anglo-normand»: Robert fils-Gautier et l'héritage de Valognes}

\author{
Daniel POWER \\ Swansea University \\ Department of History and Classics \\ d.j.power@swansea.ac.uk
}

\begin{abstract}
:
The collapse of the 'Anglo-Norman realm' in 1204 placed the Anglo-Norman aristocracy in an uneviable position, as most of its members were forced to choose between keeping their English or their French lands. The process of untangling the ties between the two countries in the ensuing decades has received little attention from historians. The present article considers the evidence of communication after 1204 between the English magnate Robert fitzWalter and French royal officials in Normandy, which was intended to resolve problems arising from charters that Robert and his wife Gunnor de Valognes had issued in favour of the priory of Notre-Dame-du-Pré before the collapse of the Angevin régime. These acts provide a revealing example of English interest and involvement in Norman affairs in the years following the Capetian annexation of Normandy, despite the continuing hostilities between the kings of England and France.
\end{abstract}

Keywords: Robert fitzWalter, Notre-Dame-du-Pré, Gunnor de Valognes, Anglo-Norman aristocracy, Capetian annexation of Normandy, cross-Channel communication, England, Normandy, charter, forgery, the $13^{\text {th }}$ century, royal officials, inheritance.

Résumé:

L'effondrement du «royaume anglo-normand» en 1204 a placé l'aristocratie anglo-normande dans une position intenable, car la plupart de ses membres ont été forcés de choisir entre conserver leurs terres anglaises ou françaises. Les manières de démêler les liens entre les deux pays dans les décennies qui suivirent ont reçu peu d'attention des historiens. Cet article examine la communication qui était destinée à résoudre les problèmes, après 1204, entre le magnat anglais Robert fitzWalter et les officiers royaux français en Normandie à partir du témoignage des chartes que Robert et sa femme Gunnor de Valognes avaient émises en faveur du prieuré de Notre-Dame-du-Pré avant l'effondrement du régime Plantagenêt. Ces actes

1. The research for this article was generously supported by the British Academy. It is dedicated to Sir James Holt, whose research has revealed so much about Robert fitzWalter and his fellow barons. In the notes below, $\mathrm{VCH}=$ Victoria County History. 
fournissent un exemple révélateur de l'intérêt anglais et de l'implication anglaise dans les affaires normandes dans les années postérieures à l'annexion capétienne de la Normandie, en dépit de la poursuite des hostilités entre les rois d'Angleterre et la France.

Mots-clés: Robert fils-Gautier, Notre-Dame-du-Pré, Gunnor de Valognes, communication trans-Manche, officiers royaux, Angleterre, Normandie, charte, faux, le XIII siècle, aristocratie anglo-normande, l'annexion capétienne de Normandie, héritage.

The fall of Normandy to King Philip Augustus of France in 1204 marked a decisive point in the history of both countries. Within a few short weeks, the Capetian king brought the 'stiff-necked' duchy under his thumb ${ }^{2}$, nearly a century and a half after the Norman Conquest of England had first established a dynastic union between Normandy and England. As contemporaries recognised, the collapse of the duchy placed the Anglo-Norman aristocracy in a painful dilemma. Since 1066 a great many of its members had enjoyed a lifestyle divided between England and Northern France, holding estates on both sides of the English Channel and sharing a single Anglo-French culture. All of a sudden, Philip Augustus' victory forced these landowners to choose between their lands on the Continent and in the British Isles.

In England, King John issued a general command to royal officials to seize the estates of all Normans, probably in the summer of $1204^{3}$. In Normandy, some redistribution was effected by the king of France, not least during his triumphal campaign through central Normandy in spring 1204, but he granted a period of grace in which landowners could do homage to him for their Norman lands, and it is likely that a full policy of confiscation was implemented in Normandy only from Easter 1205 onwards $^{4}$. It was one thing for each king to issue a general order to confiscate the lands of those who remained overseas; it was quite another to carry out these orders in practice. In both England and Normandy, royal officials struggled to establish what was to be seized by holding inquests and compiling lengthy lists of fiefs ${ }^{5}$; but since a number of landowners changed their minds about their decisions or managed to recover their lost lands by royal grace, any such lists must have quickly become out of date. The inquests of Louis IX would later uncover a great many examples of mistaken or malicious confiscations by French royal officials ${ }^{6}$. In England, political considerations

2. 'cervicosa Normannia': STEvenson, Coggeshall, p. 146, describing the duchy's subjugation.

3. The order is mentioned in HARDY, Rotuli de oblatis, e.g. p. 334 ('occasione generalis precepti facti de terris Normannorum', 1205). For the confiscations of the 'lands of the Normans' in England, See MOORE, 2010.

4. Delaborde, Actes de Philippe Auguste, ii, no 901; cf. History of William Marshal, ii (Meyer, Histoire de Guillaume le Maréchal), ii, lines 12866-74. A general royal order for confiscation is mentioned in Grosse-Duperon and Gouvrion, Cartulaire de Fontaine-Daniel, no. LXIV.

5. E.g. HARdy, Rotuli de oblatis, p. 122-143; Book of Fees, passim; NorTIER, 1995, p. 55-68; BOUQUET, Recueil des Historiens des Gaules et de la France, [hereafter RHF], xxiii, p. 606-723, and BALDwIN, Registres de Philippe Auguste, i (texte).

6. 'Querimoniæ Normannorum', in RHF, xxiv, I, p. 1-74. 
meant that greater laxity was sometimes afforded to those from regions other than Normandy, such as Flanders, Ponthieu, or Brittany, or to certain social groups, such as clerics or widows; but royal indulgence of this type was both inconsistent and intermittent ${ }^{7}$. In consequence, on both sides of the Channel there was great potential for confusion or dispute over the status of the property of Anglo-Norman landowners.

The Anglo-Norman aristocracy was effectively split down the middle, but many of its members attempted to maintain their interests on both sides of the sea. The actual mechanics of separation have received little attention from historians, not least because most of the charters for the English and Norman aristocracy of the period remain unpublished and largely unanalysed. Yet this process is essential to our understanding of the absorption of Normandy into the kingdom of France and of the disintegration of the Anglo-Norman 'realm', which had dominated northwest European politics for nearly a century and a half. Much further research is still required, for instance, to explain why there were so few manifestations of pro-Angevin sentiment in the duchy after 1204, especially during the Bouvines War of 1213-14. The present article aims to cast light upon the twin processes of the separation of England and Normandy and the assimilation of Normandy into the Capetian realm. It draws upon a series of hitherto unpublished charters that reveal the contacts between Robert fitzWalter, one of the most famous magnates in medieval England, and a portion of his wife's property in the Pays de Bray in northeast Normandy. The texts reveal some of the means by which the Capetian baillis sought to control the duchy of Normandy in the early years of the French régime, and they furnish a revealing glimpse of the process of disengagement between the two countries.

\section{Communications between England and Normandy after 1204}

In order to understand the documents in question, which all concerned the rights of the priory of Notre-Dame-du-Pré (alias Bonne-Nouvelle) near Rouen, it is first necessary to consider the problems confronting the Capetian officials in Normandy. The king of France's baillis were hampered by their own ignorance of the province that had fallen under their sway. In order to administer Normandy effectively and fairly, they needed a good knowledge of the genealogies of each and every landed family in the duchy. If a Norman landowner died and the nearest heir was believed to be in England, then the property stood to fall into royal hands; and in theory this required the baillis to have accurate details about the branches of Norman landed families across the sea. The Capetian bailiffs also need a knowledge of the Norman past. Capetian acts and judgments at the Norman exchequer usually appealed to conditions 'as in the time of King

7. For these and related issues, see Powicke, 1961, p. 286-90, p. 328-358; STEvenson, 1974; Thомpson, 2003, p. 179-187; Power, 2003a, p. 189-209. I shall discuss these privileged groups at greater length in a forthcoming monograph concerning the Anglo-Norman aristocracy between 1204 and 1259. 
Henry and King Richard', implicitly nullifying the reign of King John but also setting in motion numerous inquests to ascertain the conditions before $1199^{8}$. Yet the bailiffs were mostly incomers from the French royal domain, and many of the people best informed to provide such information had retreated across the Channel in 1204. In England, royal officials were not constrained by the political situation to return conditions to the situation before 1199, but like their French counterparts they needed to know the fate of Anglo-Norman heirs who had remained overseas.

Consequently, one of the chief paradoxes of the separation of England and Normandy was that connections between the two countries could not be completely severed if their rulers were to exert the maximum control over their kingdoms but also rule with equity. It was also in the interest of their subjects to keep channels of communication open. Some Normans plotted for the return of the Angevin dynasty, while others stood to inherit property across the sea if more senior relatives died. On numerous occasions the kings of England publicly proclaimed their intention to recover their lost fiefs, and the English royal courts regularly asserted the desire of the king and political community that England and Normandy would be reunited in due course ${ }^{9}$. On both sides of the English Channel after 1204, we may imagine that there was a climate of rumour and conspiracy, of uncertainty about the future and regret about the past. Since no formal peace was concluded until 1259, this climate of insecurity persisted for over two generations after the 'loss of Normandy'. In 1205, for instance, the chronicle of Ralph of Coggeshall reported that the French knights guarding the Norman coast were terrified into retreating inland by rumours of the imminent return of the king of England; the same chronicler also recorded widespread fear in England that the count of Boulogne and duke of Louvain would invade to make good their claims to the honour of Boulogne, joining forces with dissident English barons who had lost their French property ${ }^{10}$. At more peaceful moments, the two régimes were prepared to exchange relevant information or seek the restoration of dispossessed landowners overseas. In 1219, the Norman exchequer consulted the regency government of Henry III under William Marshal in order to establish whether a certain Ralph Huigan had died in England ${ }^{11}$, and the previous year the Marshal requested the restitution of a dispossessed Norman near Caen ${ }^{12}$. The regent

8. BALdwin, Registres de Philippe Auguste, inquisitiones.

9. POWER, 2011, p. 143.

10. Stevenson, Coggeshall, p. 148-149, p. 152. For the Boulogne-Louvain treaty, including terms for the recovery of their English rights, see Teulet, Layettes, i, $\mathrm{n}^{\text {os }} 749-750$.

11. Delisle, Jugements de l'Échiquier, $\mathrm{n}^{\mathrm{os}} 172,246$. He was presumably either Ralph fitzWigan of Willoughby (Warks.) or Ralph fitzWigan of Goldington (Beds.): Book of Fees, i, p. 8; ii, p. 1279, p. 1340; VCH Warks., vi, p. 262; Fowlen, Cartulary of Old Wardon, n' 288 and p. 332 n. 169; VCH Beds, iii, p. 205 , p. 206.

12. Delaborde, Actes de Philippe Auguste, iv, no 1512 (Feb. 1218, n.s.): William de Montigny is restored to his land in the bailliage of Caen 'ad preces karissimi amici et fidelis nostri Guillelmi marescalli', most probably the earl of Pembroke. 
of England's communications with the king of France and his governors of Normandy reflected the fact that he and his wife, Countess Isabella of Striguil, had managed to retain their Norman lands after 1204 as well as their vast estates in England, Wales and Ireland ${ }^{13}$.

The 'official' channels of communication have left their mark upon royal records in England and France. We have to assume, however, that many 'private' channels also operated, although their very nature means that they are unlikely to have left a mark upon royal records; indeed, both Normans and English must often have had strong motives for concealing communication with relatives and other contacts overseas. It is clear, for instance, that family networks continued to pass news of the deaths of landowners to potential heirs overseas ${ }^{14}$. Many religious houses of Northern France retained daughterhouses and estates in the British Isles, and their heads had to cross the sea to do homage to the king of England for their possessions in his realm. Conversely, a small number of English priories had continental property which required their representatives to cross the sea: for instance, when Merton Priory in Surrey was involved in a dispute over the church of Cahagnes (Calvados), some time between 1204 and 1211, one of its canons crossed to Normandy in an attempt to defend the priory's interests, although he complained that the whole province was against him because, unlike his adversaries, he lacked a strong local patron ${ }^{15}$. The English royal chancery rolls abound with requests for safe-conducts from religious to cross the sea. Merchants, too, continued to ask for licences from both monarchies to trade overseas, even in time of war. There were many means, then, by which news could pass back and forth across the Channel: such communication must have been substantial, for Continental French continued to have a strong lexical influence upon the French of the British Isles ${ }^{16}$.

One intriguing example of cross-Channel communication, soon after the Capetian annexation of Normandy, can be reconstructed from a set of documents preserved by the priory of Notre-Dame-du-Pré near Rouen. These reveal that in about 1208 the English baron Robert fitzWalter intervened in a dispute over his former lands at Bures-en-Bray (Seine-Maritime), which he had once held in right of his wife, Gunnor de Valognes. A detailed consideration of the history of the Valognes fief reveals the significance of Robert fitzWalter's intervention for cross-Channel communications in the aftermath of the 'loss of Normandy'.

13. POWER, 2003b, p. 199-224.

14. For discussion of one example (the Boistard family, 1242), see Power, 2003a, p. 195-1966. There are a number of other examples of heirs appearing from overseas at the death of a landowner.

15. Richardson, 1932, p. 383-392; Arnoux and MANEUVrier, 2000, p. 21-22, p. 54-57. According to the canon, Robert of Guildford, his rivals had enlisted the support of Ralph l'Abbé and Abbot Samson of Caen, who had run the Norman exchequer under King John and who were now prominent members of the new Capetian régime.

16. Trotter, 2011 


\section{The Norman inheritance of Gunnor de Valognes and the 'loss of Normandy' (1190-1204)}

Robert fitzWalter is one of the most famous (or notorious) barons in medieval English history. Lord of the barony of Little Dunmow in Essex and head of a junior branch of the great family of Clare - itself a cadet branch of the Norman ducal house - that had been promoted to great wealth by Henry I, Robert became the avowed leader of the revolt that led to King John's concession of Magna Carta in $1215^{17}$. Today the nineteenth-century statues of the 'twenty-five barons' of Magna Carta may be seen in no less a place than the House of Lords at Westminster: and pride of place is taken by Robert, who styled himself 'marshal of the army of God and Holy Church' during the crisis surrounding the Great Charter. Robert fitzWalter played a pivotal role in the resistance to King John's rule between the assassination plot of 1212, in which Robert was one the ringleaders, and in the battle of Lincoln in 1217, during which he and his son were captured. An aggressive litigant, he enlarged the barony of over sixty knights' fees that he had inherited in Essex, Hertfordshire and elsewhere ${ }^{18}$ by securing the lands of his maternal uncle Godfrey de Lucy, bishop of Winchester, and by disputing his share of the larger Lucy inheritance in Kent, Cornwall, Norfolk and elsewhere with the representatives of the senior Lucy line ${ }^{19}$.

Although the Saint Albans chronicler Matthew Paris vilified King John, he was also very hostile to Robert fitzWalter, a consequence of the baron's repeated property disputes with his abbey. Nevertheless, it is to Matthew Paris that we owe a fine description of Robert:

'Now he was strenuous in arms, spirited and proud, abounding in many possessions, generous, with a great number of powerful kinsmen, and protected and strengthened by a multitude of relatives by marriage ${ }^{20}$.

Sir James Holt has identified the many close ties of blood and association that linked Robert fitzWalter to the other rebels of $1215^{21}$. The lord of Little Dunmow's connections spread in a network across south-east England, the East Midlands

17. For the ancestry and career of Robert fitzRichard, grandfather of Robert fitzWalter, see Round, 1895, p. 355-363; KeATs-RoHAN, 2002. Round notes that the extended Clare family was sufficiently distinguished in the twelfth century to be known simply as the Ricardi, rather than by a toponymic surname.

18. Hall, Red Book, i, p. 347-349: Walter fitzRobert (father of Robert fitzWalter) answers for $63^{1 / 2}$ knights of the old enfeoffment, and $3^{1 / 4}$ of the new. Ibid., i, p. 175 (1211-1212): Robert fitzWalter has $63^{1 / 2}$ knights de propria horeditate. See Sanders, 1960, p. 129-130.

19. Hardy, Rotuli de oblatis, p. 228-229, p. 414; Curia Regis Rolls, viii, 25-6; xii, nº 136; MAITLAND Bracton's Note-Book, nº 1764; Churchill, Calendar of Kent, no 189/103. Cf. Hall, Red Book, ii, p. 539: Robert fitzWalter holds 11 knights of the fee of his (deceased) 'uncle' (cousin) Richard de Lucy.

20. Riley, Gesta Abbatum Sancti Albani, i, p. 220-221: 'Erat enim in armis strenuus, animosus, et superbus, multis abundans possessionibus, generosus, et potentum consanguineorum numerositate, et affinium septus multitudine, ac roboratus'.

21. Holt, 1984, p. 2-4, p. 20-22; repr. in his Holt, 1997, p. 224-225, p. 239-240. Cf. MiCHEL, Histoire des ducs de Normandie, p. 117-118, p. 121, for Robert's alleged boasts about the power of his 'lignage'. 
and East Anglia, linking him to, amongst others, the magnate lineages of Clare, Mandeville, Lucy, Quency, Mountfichet, and Aubigny of Belvoir; these ties were often reinforced by multiple marriages as well as by regional solidarity ${ }^{22}$. Although relations between Robert and some of his kinsmen on his mother's side would later be disrupted by inheritance disputes, his family connections appear to have played a significant part in the organisation of the rebellion against King John. It is Robert fitzWalter's 'multitude of relatives by marriage' that concern us here: specifically, his first wife Gunnor, heiress of Robert de Valognes of Benington (Herts.).

The honour of Valognes answered for about fifty knights' fees, so that Robert's marriage, through which he initially acquired two-thirds of the honour, consolidated his interests in Hertfordshire and brought him important additional concerns in Norfolk and northern England ${ }^{23}$. The marriage led Robert into a dispute with his wife's uncle, the Anglo-Scottish magnate Philip de Valognes, over the inheritance of another uncle, Geoffrey de Valognes, in Hertfordshire and four northern counties ${ }^{24}$. Gunnor's descent from former sheriffs of Hertfordshire was also the basis for Robert's claim to Hertford Castle, which Sidney Painter described as 'not very strong' but which secured him custody (1200-9) and then a hereditable claim (1215) ${ }^{25}$. The marriage also embroiled Robert in two bitter contests with the abbey of Saint Albans. The first dispute, concerning Northaw Wood (Herts.), pitched him against the abbey in the royal courts in 1200-1, but its roots lay deep in the Valognes family history, originating in the ambiguous terms of the abbey's grants of the wood to Gunnor's predecessors ${ }^{26}$.

22. Hence Robert fitzWalter married Gunnor de Valognes, whose cousin William de Valognes married a daughter of Saher de Quency, who was in turn Robert's half-cousin through the family of Senlis. Robert's two daughters by Gunnor de Valognes married the brothers Geoffrey (IV) and William (III) de Mandeville, successive earls of Essex. Richard de Mountfichet and Robert fitzWalter were first cousins through their mothers, both daughters of the justiciar Richard de Lucy, but through their fathers they were both descended from Richard of Tonbridge (d. 1090), founder of the Clare family fortunes in England. For the perils of trying to identify the political significance of Robert's more distant connections, see HoLT, 1984. The future regional dominance of Robert's kin is apparent in the Carte Baronum for Essex in 1166, where his father William fitzRobert's carta is preceded by that of Geoffrey (III) de Mandeville and followed immediately by those for Geoffrey de Valognes, William de Mountfichet, and Richard de Lucy (HaLl, Red Book, i, p. 345-354).

23. HALL, Red Book, i, p. 175 (1211-1212): Robert fitzWalter has 63¹/2 knights de propria hereditate, $33^{1 / 3}$ of the inheritance of his wife, the heir of Robert de Valognes, and 2 knights for Geoffrey de Valognes (de Gavoloniis), of the said wife's inheritance. Until 1224 one third of the Valognes inheritance was held by Gundrada de Warenne, widow of Peter II de Valognes (d. 1158-9). See Book of Fees, i, p. 574-579; SANDERS, 1960, p. 12; Round, 1904a, p. 707-711.

24. HaRdy, Rotuli de oblatis, p. 424-425, p. 428 (lands in Yorks., Lincs., Lancs. and Northumberland); Hall, Red Book, ii, p. 349; Curia Regis Rolls, v, p. 156-157, p. 158, p. 171, p. 179, p. 317; for Philip de Valognes, see below, n. 39.

25. PaINTER, 1949, p. 31, p. 331-332. At first Robert merely sought custody of Hertford Castle, but in 1215 he received it 'ut jus suum' (Curia Regis Rolls, i, p. 116; Hardy, Rotuli litterarum patentium, p. 144; HoLT, 1992, p. 166).

26. Curia Regis Rolls, i, p. 116, p. 178, p. 291, p. 339, p. 451; Baildon, Select Civil Pleas, i, no 45; Riley, Gesta Abbatum Sancti Albani, i, p. 63, p. 95, p. 159-166, p. 220-226; cf. Palgrave, Rotuli Curice Regis, ii, p. 40-41. 
The quarrel was resolved by a concord in the king's court in 1200-1 ${ }^{27}$, but another, more bitter dispute with Saint Albans raged between 1209 and 1212 over the rights of patronage over Binham Priory (Norfolk). If Matthew Paris is to be believed, it was Robert's violent treatment of the monks of Binham, whom he besieged in their priory with an armed force, that earned him the enmity of King John, who saw Robert's aggressive behaviour as a threat to royal authority ${ }^{28}$. Whether this is true or not, it is clear that Gunnor's English inheritance greatly enhanced Robert's power but also entangled him in considerable litigation and strife ${ }^{29}$.

Robert fitzWalter's actions as husband of Gunnor de Valognes in England caught the attention of his contemporaries. It is less well known that his marriage to Gunnor also brought him lands in Normandy. Robert himself does not appear to have inherited any Norman property. The lords of Dunmow were descended from a younger son of Gilbert fitzRichard, lord of Clare, but all the hereditary Norman lands of the house of Clare had passed by the mid-twelfth century to the Pembroke (Striguil) branch of the dynasty. Robert's grandfather, Robert fitzRichard, owed the bulk of his English possessions to the favour of King Henry I. Robert's father, Walter fitzRobert, had acquired Méry (now Méry-Corbon, Calvados, cant. Mézidon-Canon) through his second marriage, to Matilda de Bohun; but Robert fitzWalter was Walter fitzRobert's son by his first wife, Matilda de Lucy, and in any case, after the death of Matilda de Bohun Méry passed to her descendants by her first husband, Henry d'Oilly, rather than to Robert fitzWalter's half-brothers ${ }^{30}$. Despite a distinguished descent from the dukes and leading barons of Normandy, Robert's inheritance lay entirely in

27. Luard, Annales Monastici, iii, p. 28; Pipe Roll 2 John, p. 51.

28. Curia Regis Rolls, vi, p. 55-56, p. 133-134, p. 273, p. 284; Riley, Gesta Abbatum Sancti Albani, i, p. 226-228. See also British Library, Ms. Cotton Claud. D.xiii (Binham Priory Register), fols. 2 - 5, for early Valognes acts for the priory. The records of the king's court also show Robert waging disputes over Gunnor's inheritance with the nuns of Holywell (London) and William de Vescy.

29. For his disputes over the Valognes lands after 1232, see Book of Fees, i, p. 574.

30. Rouen, Arch. dép. Seine-Maritime, 20 HP 5: Matilda, daughter of Humphrey de Bohun, grants the church of Meri to Notre-Dame-du-Pré, with the consent of her lord Walter fitzRobert, for the soul of her son Thomas (s.d., late $12^{\text {th }}$ C.). The identification of Meri with Méry-Corbon comes from Pouillés de Rouen, 114, which states that the church's patron c.1350 was the abbot of Bec-Hellouin, of which Notre-Dame-du-Pré was a dependency. The earliest ancestors of the Bohuns had borne the surname de Meri. Matilda de Bohun had previously been married to Henry d'Oilly or d'Ouilly (Keats-Rohan, 2002, p. 620-621); under Philip Augustus a fief at Mereium was held by the archdeacon of Angers, probably William d'Ouilly (RHF, xxiii, 619d (cf. 706c, 715 l), who is not listed in Fasti Ecclesiae Gallicanae, 7, p. 132-135). Méry presumably escheated to the French crown with William d'Ouilly's other lands at his death, c.1231, when his nearest heirs were allegedly in England, although Joanna d'Ouilly, one of his father's cousins and a Norman resident, later claimed to be the next heir ('Querimoniæ Normannorum', nº 370-371, p. 383, p. 410, which show that the family took its name from Ouilly-le-Tesson, CA, cant. Bretteville-sur-Laize). Round, 1900, p. 329-330, mistakenly places Méry in the département of La Manche. Matilda de Bohun had at least two sons by Walter fitzRobert, namely Walter, precentor of London, and Thomas, while Simon fitzWalter, lord of Daventry, was probably her son as well; but there is no evidence that they inherited any of their mother's Norman dowry. For these sons, see Matilda's act for Notre-Dame-du-Pré (Rouen, Arch. dép. Seine-Maritime, 20 HP 5); Round, 1900, p. 329-330; Franklin, The Cartulary of Daventry Priory, p. xxi and n ${ }^{\circ}$ 9-16, p. 177. 
England. However, his marriage to Gunnor de Valognes between 1194 and 1199 turned him into a Norman landowner ${ }^{31}$. Gunnor's Norman lands were modest in size, but Robert was prepared to pay them considerable attention. His active, if inglorious participation in the defence of Normandy may have owed something to his recent acquisition of property in the duchy through his marriage, and we shall see that his concern for this property would outlast the collapse of the Angevin régime in $1204^{32}$.

Gunnor's known Norman property lay not, as might be expected, near the town in the Cotentin from which her family derived its surname, but at the opposite end of the duchy, on the fringes of the Pays de Caux and the Pays de Bray. The location of this land and its fate under Robert fitzWalter are revealed by a series of charters for Notre-Dame-du-Pré, a distinguished priory of the great abbey of Bec-Hellouin. Situated on the left bank of the River Seine in the Rouen suburb of Ermentreville (now Saint-Séver), Notre-Dame-du-Pré, also known as Bonne-Nouvelle, had been founded by Matilda of Flanders, wife of William the Conqueror, and its benefactors included Robert Curthose, Henry I, Empress Matilda and Geoffrey of Anjou, and the archbishops of Rouen ${ }^{33}$. As a convenient semi-rural residence outside the ducal capital, it was a popular staging post for the rulers of the duchy and their leading subjects. It was here that Robert Curthose had sheltered during the rebellion of the citizens of Rouen in 1090, and Hubert Walter, archbishop of Canterbury, was lodging here when he heard the news of Richard I's death in 1199; one tradition also made it the site of the clandestine burial of Arthur of Brittany after his murder in $1203^{34}$. In the late twelfth century Notre-Dame-du-Pré enjoyed the patronage of a number of baronial families from Upper Normandy, including the earls Warenne and Robert fitzWalter's own father and stepmother Matilda de Bohun; both she and Earl Hamelin de Warenne had younger sons buried there ${ }^{35}$. The priory was actively building up its estates in and around Bures-en-Bray, and so an endowment from the Valognes fief at Bures was a natural step for Robert and Gunnor to $\mathrm{make}^{36}$.

31. Gunnor's first husband apparently died in 1193-1194 (Pipe Roll 6 Richard I, p. 64; Robert had acquired the Valognes inheritance in England by Mich. 1198 (Pipe Roll 10 Richard I, p. 135; cf. RichaRdson, Memoranda Roll for the First Year of King John, p. 77).

32. Below, p. 12-14.

33. Rouen, Arch. dép. Seine-Maritime, $20 \mathrm{HP} 5$, contains numerous ducal acts from Robert Curthose onwards.

34. Chibnall, Orderic Vitalis, iv, p. 222-224; History of William Marshal, ii (Meyer, Histoire de Guillaume le Maréchal, ii), lines 11844-7, although it is conceivable that this was the archbishop of Rouen. For Arthur's burial at Notre-Dame-du-Pré, see Luard, Annales Monastici, i, p. 27; cf. Powicke, 1961, p. 316, p. 319.

35. Rouen, Arch. dép. Seine-Maritime, 20 HP 5: acts concerning the grant of rights in the church of Louvetot (Seine-Maritime, cant. Bellencombre, c. Grigneuseville) by Earl William de Warenne, whose brothers were buried in the chapter of Notre-Dame-du-Pré (1203). For Matilda de Bohun's son Thomas, see above, n. 30 .

36. Rouen, Arch. dép. Seine-Maritime, $20 \mathrm{HP} 1$; cf. $55 \mathrm{HP}$ 4, the abbey of St-Amand grants all its property in the manor of Bures and its dependent ville to the priory of Notre-Dame-du-Pré (8 May 1209). 
Gunnor de Valognes had first patronised the priory before her marriage to Robert fitzWalter. Soon after the death of her father Robert in 1183-4 she was married to Durand de Hostilleio or de Ostilli, apparently a minor familiaris of Henry II, possibly from Outillé in Maine ${ }^{37}$. If he was indeed Manceau by origin, Durand was a rare example of Henry intruding a man from Greater Anjou into an Anglo-Norman inheritance ${ }^{38}$. We first learn of the Valognes lands in Normandy from an act of Durand and Gunnor in 1190 for Notre-Dame-du-Pré (Appendix, $\mathrm{n}^{\circ}$ 1). At the petition of Philip and John de Valognes ${ }^{39}$, the couple granted their land, homestead (mainillum), wood, meadows and pastures in the fief of Valognes at Bures-en-Bray, near Neufchâtel-en-Bray, to the priory, for the sake of the souls of Gunnor's parents Robert de Valognes and Hawise and two other named people called Geoffrey Dier' and Tiphaine. In return, the monks paid Durand and Gunnor a sum of 150 livres angevins and an annual payment of 10 livres angevins per annum, which the monks were not required to begin paying until $1202^{40}$. At the time Durand was raising cash in order to join the Third Crusade, from which he did not return ${ }^{41}$.

The Valognes lands in Normandy therefore appear modest: a single fief at Bures - no doubt based around the farm now known as La Valouine ${ }^{42}$ - worth only 10 li. ang. (£2 10s. sterling) a year. Moreover, the first time we encounter its Norman interests, the Valognes family was divesting itself of any land in return for a regular cash income that was to be paid at Durand's estate of Hostilleium. After Gunnor's marriage to Robert fitzWalter, he issued an act confirming the terms of her grant to Notre-Dame-du-Pré (Appendix, $n^{\circ}{ }_{2}$ ), but he quickly took a firm grip of her revenues at Bures. By the time the monks began paying the

37. Delisle, Catalogue des actes de Philippe Auguste, index (cf. ${ }^{\circ}{ }_{1373}, 1448$ ), identifies Hostilleium as St-Mars d'Outillé (Sarthe, ar. Le Mans, cant. Écommoy). A William de Ostilli appears as a frequent witness for King Henry II; Gallia Christiana, xi, col. 484, also refers to Bishop William Borel II of Avranches (1210-1236) as de Ostilleio. However, there was an insula Ostelli in the diocese of Rouen, perhaps in the Seine or one of its tributaries such as the River Andelle (RAmackers, Papsturkunden in Frankreich, Normandie, $\mathrm{n}^{\circ}$ 115, a very faulty text). A location near Rouen would explain why the monks were to receive payment at Hostilli (see Appendix, $\mathrm{n}^{\circ}$ 1).

Durand had custody of Gunnor, and had possibly married her, by 1185 (Round, Rotuli de dominabus, p. 87 and n. 2), and certainly before Henry II's death (Curia Regis Rolls, i, p. 277-278); cf. P.R. 2 Richard I, p. 109.

38. Cf. VINCENT, 2000, p. 119-126, for the paucity of Angevins and Poitevins rewarded by Henry II with marriages or lands in England.

39. For Gunnor's uncle Philip de Valognes, constable of Scotland (d. 1215), see Barrow, Acts of William I, passim; STRINGER, 2004, lvi, p. 66-67. After the death of Christina, younger daughter of Robert fitzWalter and Gunnor, in 1233, and of Robert himself in 1235, the Valognes inheritance passed to Philip's granddaughters (SANDERs, 1960, p. 12-13). John de Valognes, clerk, may have been another uncle of Gunnor but is not recorded elsewhere (Round, 1904b, p. 29-35).

40. The act says ' 13 years after the first coronation of Richard I', i.e. 3 Sept. 1202. Since the payment was due on St Christopher's Day (25 July), we might expect the first payment to be made on 25 July 1203; but Robert's grant of the revenues to Gerard de Gournay by '1202' (i.e. before 25 Mar. 1203) shows that he was already receiving them by then.

41. Curia Regis Rolls, i, p. 69, p. 277-278.

42. La Valouine, Seine-Maritime, cant. Londinières, c. Osmoy-St-Valéry, the adjacent commune to Bures-en-Bray (also cant. Londinières). 
10 li. per annum to Gunnor in 1202, Robert had granted away one half of the pension (10os. ang.) to a certain Gerard, prévôt of Gournay, and his son Odo ${ }^{43}$, and Gunnor had remitted the other half to the monks for the sake of the soul of Robert's cousin Richard de Mountfichet ${ }^{44}$. These grants represented the interests of Robert fitzWalter rather than Gunnor herself: he had diverted a portion of his wife's inheritance for the sake of his own kin, and used another portion to entice a local man from eastern Normandy into his service, and in the process, the Valognes interest at Bures had been reduced still further. Nevertheless, Gunnor issued an act in 1202 confirming both grants (Appendix, $n^{\circ} 3$ ). Presumably this grants were made now because the monks began paying the pension in 1202 , when their thirteen years of grace came to an end.

The further reduction of their property at Bures might suggest that Robert and Gunnor were attempting to divest themselves of their modest Norman property at a time when the duchy was under severe threat from the king of France. Yet the grant for the soul of Richard de Mountfichet shows that the Anglo-Norman realm was still very much in existence in 1202. Alms for a dead 'English' baron were being instituted by another 'English' baron from Norman revenues. Furthermore, Robert played a very active part in the affairs of Upper Normandy at this time, both on his own account and that of the beleaguered king of England. He was active in trade in the region: in February 1203 he had two ships on the Seine, one carrying wine from the French royal domain, the other taking salt - presumably in the opposite direction, from the Norman coast to inland France ${ }^{45}$. Meanwhile, in spring and autumn 1201, the count of Eu had risen in arms against King John at Drincourt (Neufchâtel-en-Bray), a mere $6 \mathrm{~km}$. from Bures-en-Bray, leading to renewed Angevin-Capetian war and, eventually, the French conquest of Normandy. We find a number of echoes of war in the charters and activities of Robert and Gunnor in this period. Gunnor's act of 1202 was witnessed by the count and countess of Aumale, whose Norman county succumbed to French invasion that summer ${ }^{46}$. When Robert enfeoffed the prévôt of

43. I have not come across the prévôt of Gournay or his son in the acts of the lords of Gournay or other documents concerning that lordship. It is possible that Gerard and Odo were related to Hugh de Brémontier (fl. 1175), one of the knights of Hugh, lord of Gournay, and son of a certain Odo the prévôt (Évreux, AD Eure, $\mathrm{H}$ 86); Hugh's son Odo de Brémontier wavered between Normandy and England until at least 1207, but his family most probably chose to remain in Normandy. See Salter, The Thame Cartulary, i, no 45, 6o, 62-64, 66-72; Hardy, Rotuli Normannio, p. 142; HaRdy, Rotuli Chartarum, i, p. 141; HaRdy, Rotuli Clausarum, i, p. 20, p. 79; Delisle, Recueil des Jugements, $\mathrm{n}^{\circ} 834$; RHF, xxiii, p. 746, p. 752; SAlter, The feet of fines, $\mathrm{n}^{\circ} 85$; VCH Oxon., vii, p. 174 (misidentifying Brémontier as Brémoy (Calvados)).

44. For Richard de Mountfichet (Montfiquet) of Stansted Mountfichet and his family, see Sanders, 1960, p. 83; KEATS-RoHAN, 2002, p. 595-596. Like Robert fitzWalter, he was the son of a daughter of Richard de Lucy, justiciar of Henry II: see CRR, xii, $\mathrm{n}^{\circ}$ 136, and below, Appendix II (Table II).

45. HARDY, Rotuli Normannice, p. 78.

46. For Hawise, countess of Aumale, and her third husband Baldwin de Béthune, see Complete Peerage, p. 353-355; English, 1979, especially p. 32-37; Power, 2004, p. 284-285, 415n., 484 ; for the fall of the county of Aumale, see ibid., p. 424-427, p. 532-538. The fortress of Aumale itself had fallen to the French in 1196 and its recovery by the Normans thereafter is uncertain (ibid., p. 415). 
Gournay and his son with cash revenues at Bures, it is quite possible that this was to compensate him for losses suffered because of the French capture of Gournay in July 1202. He was a frequent witness for royal acts issued in the Seine valley at this time, including one in April 1203 in which King John fulminated against the count of Sées for his betrayal of Alençon ${ }^{47}$. On a number of occasions he appears with his cousin and comrade-in-arms Saher de Quency, and in July 1203, Robert and Saher earned the ignominy of their contemporaries for their over-hasty surrender of Le Vaudreuil to the king of France. Both noblemen were held to have shamed the English who had previously vaunted the stubbornness of their resistance to the French by comparison with the Normans ${ }^{48}$. Robert endured a harsh imprisonment in Compiègne at the hands of Philip Augustus, who held him in contempt, and probably remained hors de combat until just before the surrender of Rouen the following year ${ }^{49}$.

\section{Robert fitzWalter and the bailli of the king of France (1204-1208)}

With his return to England, Robert fitzWalter might have expected that any contact with his wife's Norman property was now at an end. He came back to France in 1206 with King John, witnessing the truce between the kings of England and France at Thouars in October, but it is very unlikely that he would have been able to visit Normandy ${ }^{50}$. Yet a few years later, he intervened in a dispute between the monks of Notre-Dame-du-Pré and the prévôt of Gournay over the fief of Valognes. An undated letter survives in which Robert informs the 'baillis and sergeants of the lord king of Gaul of Arques and Rouen' that he had ceded all his rights in the manor of Bures in the fief of Valognes to the priory in return for 10os. currentis monete a year (Appendix, $n^{\circ} 4$ ). Robert then stated that if Gerard the prévôt of Gournay and his son or anyone else impleaded the monks concerning his alms to the priory, the monks would be being troubled unjustly. Although addressed to the royal officers, its preservation amongst the muniments of Notre-Dame-du-Pré shows that the surviving exemplar was intended for the monks.

The letter raises some important questions. Firstly, when was it sent? It must postdate the surrender of Arques and Rouen to Philip Augustus in

47. POWER, 2001, p. 458-462.

48. Stevenson, Coggeshall, p. 143-144; Michel, Histoire des ducs de Normandie, p. 97; PARIS, Chronica Majora, ii, p. 482, and HARDY, Rotuli patentium, p. 34-35, p. 37 (their ransoms). I disagree with Powicke's assertion (Powicke, 1961, p. 162), based on the passage from Coggeshall, that the two nobles became the subject of 'satirical doggerel': canticum, literally 'song' or 'canticle', here seems to mean 'reputation'. Powicke also errs in stating that the Normans saw the surrender of Le Vaudreuil as proof of 'English indifference', on the basis of the Histoire des ducs de Normandie; the text actually maintains that the English had previously accused the Normans of being too ready to surrender castles. For Robert's comradeship with Saher, see HoLT, 1984, p. 21-22 (HoLT, 1997, p. 240).

49. Saher de Quency had returned to King John's court by 5 May 1204 (Hardy, Rotuli Chartarum, p. 133).

50. Rymer, Fodera, i, I, p. 95 (Baldwin, Registres de Philippe Auguste, p. 497-499). 
June 1204, and must predate a series of acts from 1208 that will be discussed below $^{51}$. Secondly, to what act was Robert referring in his letter? No surviving charter of Robert fitzWalter makes a grant in the way that he describes. However, Gunnor's act of $1202\left(\mathrm{n}^{\circ} 3\right)$ had the same effect as the grant set out in Robert's letter: by her act, the 10os. that the monks were still required to render to Gunnor and Robert had been remitted to the priory, for the soul of one of Robert's relatives. Robert fitzWalter's letter appears to represent his own recollection of the transaction of 1202, which may mean that he had no available written record of his earlier acts.

Two other questions are the most important. Was the act produced in England, or was Robert able to visit Normandy after 1204? The letter shows at once Robert's detachment and familiarity with the situation in Normandy: 'manor' was an unusual term in Normandy at this date and its use here may have given the letter an English quality, but the substitution of 'current money' for sous angevins shows that Robert was aware of the reform of the Norman coinage by Philip Augustus in $1204^{52}$. Yet the balance of probabilities is that the letter was sent from England. If so, how did Robert become aware in England that his Norman alms were in danger? The royal truce of October 1206 may have allowed easier contact across the Channel, although relations between the two kingdoms remained tense, with desultory clashes in Brittany and Poitou over the next few years ${ }^{53}$. Most probably a monk of Notre-Dame-du-Pré, or perhaps the mother house of Bec, sought him out and asked him for help; the abbey retained much land in England after $1204^{54}$. This must remain mere speculation, but it is difficult to see how else such news could have reached him. With the soul of his deceased cousin at risk, the lord of Little Dunmow sent a writ to the Capetian bailli in an attempt to protect his and his wife's gifts in alms.

Robert's intervention appears to have arisen from an attempt by the prévôt of Gournay and his son to appropriate the whole pension of $10 \mathrm{li}$. that the monks had been accustomed to render. No doubt Gerard and Odo were profitting from the absence of Robert and Gunnor, whom they must have regarded as powerless to warrant their alms to the monks against their interference. The details of this dispute can be deduced from three further deeds, issued in 1208. In two acts in favour of Notre-Dame-du-Pré, Gerard and Odo de Gournay sold the pension of 100 s. that Robert fitzWalter had granted them for life (Appendix, $\left.n^{0} 5-6\right)^{55}$.

51. See below, p. 15-16. Although this act could date from the exile of Robert fitzWalter in 1212-1213, it seems to prefigure the transaction of 1208 recorded in $n^{\circ} 5$ and 6 below.

52. 'Current money' was becoming common for monetary reasons before 1204, but its substitution for angevins in this act appears to be a direct response to the change in coinage in that year. See Delisle, Catalogue de Philippe Auguste, n 112.

53. Power, 2004, p. 446-466. In Apr. 1208 King Philip alleged that King John's men had broken the truce (Delaborde, Actes de Philippe Auguste, iii, $\mathrm{n}^{\circ}$ 1021).

54. Morgan, 1946, p. 120. Some of Bec's property was seized in 1204 but was soon restored.

55. It should be noted that the text of neither act is completely satisfactory: much of $n^{\circ} 5$ is missing, while $n^{\circ} 6$ is known only from a Trésor des Chartes copy of a vidimus of 1347 , although its terms 
The monks were thereby freed of the obligation to pay any sum for the fief of Valognes, at least for the term of Gerard's and Odo's lives. Both acts issued by Gerard and Odo stated that the sale was enacted in the presence of the castellan of Arques, John de Rouvray (one of the acts also called him 'justice'), and in a third act, given at Rouen in April 1208, the castellan issued a notification of the terms of the sale (Appendix, $n^{\circ} 7$ ). It is easy to believe that Robert's letter to 'the baillis and sergeants of Arques and Rouen' had been sent to John de Rouvray; perhaps the Capetian official had even solicited it from Robert through an intermediary.

John de Rouvray's role in this example of Anglo-Norman communication after 1204 is interesting. Although most of the Capetian baillis were from the French royal domain, John was a Norman, the scion of a lignage chevaleresque from Rouvray-Catillon in the Pays de Bray. Some of his family's estates and his acquisitions lay within a few miles of Bures-en-Bray. A rebel against Richard I and in French royal service from 1194, John returned to 1202-3 to administer the marcher districts around his place of origin that had fallen into French hands, and in 1204 he assisted the king of France in negotiating the surrender of Norman castles. From 1204 to $c .1210$ John de Rouvray held the title of castellan of Arques but, as Delisle noted, he was the first Capetian bailli of Caux in all but name. In this role he crushed an attempt by Roger de Mortemer to revive King John's cause at Dieppe in 1205, and ruthlessly asserted royal rights in northeast Normandy ${ }^{56}$. It must be assumed that Robert fitzWalter's letter to John de Rouvray and the castellan of Rouen ${ }^{57}$ had the desired effect. The monks' preservation of the letter shows that the residuary rights of Robert - and, by extension, of Gunnor - were still acknowledged in Normandy, and that his word still carried some weight there, despite the confiscation of the estates of those who had remained in England.

\section{The forged act of Gunnor de Valognes ('1209')}

In August 1212, Robert fitzWalter was outlawed for his part in the assassination plot against King John, and fled to France ${ }^{58}$. Whether Gunnor accompanied him is not known; nor is there any indication whether he visited Normandy during his months of exile. After his return to England in 1213 there is no further indication of any contact between Gunnor and her family and her Norman inheritance. John de Rouvray's act of 1208 did not mark the end of the troubles over the fief of Valognes, however. The muniments of NotreDame-du-Pré include another purported original act of Gunnor, dated 1209 (Appendix, $\mathrm{n}^{\circ}$ 8). By this act, 'Gunnor, daughter and heir of Robert de Valognes, widow (relicta) of the late Robert fitzWalter', ceded all her

appear authentic.

56. RHF, xxiv, I, préface, p. 109*-110*; Power, 1997, p. 361-384; see also PowER, 1999, p. 134-135.

57. William Poucin (to 1207); William Escuacol (from c.1208): RHF, xxiv, I, préface, p. $98^{*}-99^{*}$.

58. HoLt, 1961, p. 79-83. 
remaining rights over the fief of Valognes at Bures to the monks of Bec at Notre-Dame-du-Pré. Specifically, the act stated that Gunnor had sold the monks her reversionary rights to the 10os. ang. per annum that Gerard and Odo de Gournay would receive for life from the fief. For this concession the monks had paid her 15 li. angevins.

Although it was sealed as if it were an authentic document, this act is all too obviously spurious. Although the script replicates some features of early thirteenth-century charter hands, it also contains features that suggest a date from the late thirteenth or, more probably, the early fourteenth century ${ }^{59}$, and its orthography for some proper names conforms to that period rather than $1209^{60}$. Nor is it merely the rescript of a lost original, for the text of the act contains several blatant errors. Firstly, Gunnor was never Robert's widow. In 1209 the most dramatic episodes in Robert's career still lay several years in the future, and he was destined to outlive his first wife by many years; indeed, at his death in 1235 his inheritance passed to his son by his second wife Rohese. Relicta could on occasion signify a divorced wife, but there is no evidence that Robert and Gunnor ever divorced: they acted together in the Binham Priory dispute in 1210-11, and after Gunnor's death Robert retained control of her share of the Valognes inheritance in England until his death, by the practice later known as the 'courtesy of England' 61 . The references to the money of Angers are also grounds for suspicion, for this coinage had been suppressed by Philip Augustus in 1204 and ceased to be a money of account in Normandy almost immediately ${ }^{62}$. Other features, insignificant on their own, underline the suspect nature of the act. It is the only one in the set to describe the monks of Notre-Dame-du-Pré as Beccenses, for instance: it was still unusual for Norman acts to refer to monastic daughter houses by the mother order in this way at the beginning of the thirteenth century. There can be no doubt that the extant act concerning the Valognes inheritance at Bures is a forgery.

The inauthentic nature of this act raises several interesting questions, with implications for the connections between England and Normandy after 1204. Are any other Valognes acts spurious? Was Gunnor's forged act concocted to replace a genuine act issued in her name - from which the seal may have been taken? Most important of all, who forged the act of '1209', and why?

There is no reason to regard the other Bures acts as inauthentic: none of the objections raised against the act of '1209' applies to the other seven acts, all but one of which $\left(n^{\circ} 6\right)$ appear to be authentic originals. It is certainly possible

59. I am enormously grateful to Tessa Webber for her advice regarding this unusual hand, which may represent the attempt by an early fourteenth-century clerk versed in bookhand to imitate an early thirteenth-century charter.

60. It has Vill'o instead of Will'o or Wil'o, which were the conventional Norman abbreviations in the early $13^{\text {th }}$ century for Willelmus and Willermus.

61. Curia Regis Rolls, vi, p. 133-134 (cf. p. 55-56); Book of Fees, i, p. 574. For the 'courtesy of England', see Pollock and Maitland, 1968, ii, p. 414-420. Hall, Glanvill, p. 63.

62. I am preparing an article concerning coinage in the Angevin Empire which will discuss this change. 
that the spurious act was adapted from a lost authentic act of Gunnor. Seven of the nine witnesses in the act of '1209' had witnessed either one or both of her previous grants concerning Bures, in 1190 and 1202 (Appendix, $\left.n^{\circ} 1,3\right)^{63}$. Either the forged act was adapted from a lost original - presumably one dating from before 1204, in view of the references to the money of Angers - or else the forger had the acts of 1190 and 1202 before him and took the names of witnesses from them. Too little of the seal remains to establish whether it, too, is inauthentic, or taken from an act issued by someone else, or else an authentic seal taken from a genuine act of Gunnor de Valognes.

The possible reasons for the forgery are the most intriguing aspect of this charter. The residence of Robert and Gunnor in England after 1204 left unresolved what would happen to the pension from Bures which the monks had to pay to Gerard and Odo de Gournay when these two men died. They had sold their annual pension of 100 s. to the priory in 1208, but this grant would lapse with their deaths; in theory, the pension would revert to Gunnor or her heirs. We do not know when the prévôt of Gournay and his son died, but whenever their deaths occurred, the political rift between England and France must have made it highly unlikely that Gunnor, Robert or their heirs had any chance of recovering their pension. What happened to the 100 sous a year from Bures? Perhaps this render was quietly merged into the priory's revenues. The forgery of Gunnor's act suggests, though, that in the late thirteenth or early fourteenth century the rights of Bec over the whole fief of Valognes at Bures came to be challenged. In 1302, the bailli of Caux held a sworn inquest to determine the seigneurial rights of the abbey at Bec in the fief of Valognes ${ }^{64}$. Perhaps it was because of such threats that the monks decided to forge an act in Gunnor's name that prevented any further claim being made against them. It is tempting to believe that the date of '1209' was added simply to ensure that this act postdated Gerard's and Odo's sale of their life-interest at Bures to the priory in 1208. The description of Gunnor as a widow may also have served to counter any rival claims, whereas a forged act in Robert's name could have been challenged as the act of an English baron issued after the Capetian confiscations of AngloNorman lands in Normandy.

These ruses succeeded, for in 1347, when King Philip VI issued a vidimus of the privileges for the abbey of Bec in the fief of Valognes, the spurious act of 1209 was one of those that he confirmed ${ }^{65}$. In the early fifteenth century an inventory of the acts, endorsed as Ordo litterarum de Valognes, was drawn up, presumably for renewed confirmation (Appendix, $n^{\circ}$ 9): it, too, included Gunnor's spurious act as if it were genuine.

63. 1190: Richard Marshal, William de Tourpes, Augustine d'Envermeu, Renaud de Meneres. 1202: Thomas de Vere, Richard Marshal, Geoffrey le Gros, Hugh de Bures. Thomas may have died in 1204 (below, n. 82).

64. Rouen, Arch. dép. Seine-Maritime, 20 HP 6: aprise before the bailli of Caux, in the presence of Philip de Ricarville, knight (Arques, 17 June 1302).

65. AN, JJ 68, fol. 473v: FAWTIER, Registres du Trésor des Chartes, iii, Inventaire analytique, $\mathrm{n}^{\circ} 2619$. 


\section{Conclusions}

In 1190 Gunnor de Valognes and her first husband handed over their Norman property to the monks of Notre-Dame-du-Pré in return for a cash sum and a future pension. When that annuity matured, thirteen years later, Gunnor and her second husband Robert fitzWalter remitted one half to endow prayers for their kinsman, and granted the other half away for life to a humble official. But for the 'loss of Normandy' in 1204, these grants might have passed almost unnoticed. The establishment of the Capetian régime, however, threatened all the contracts and alms in Normandy of the Anglo-Norman lords who took refuge in England, for they appeared to be in no position to warrant their grants. While the kings of France issued charters of confirmation for a number of major grants, the sort of small gift considered here was unlikely to receive such protection. The monks of Notre-Dame-du-Pré somehow managed to secure a letter from Robert fitzWalter that informed the new Capetian officials of his previous grants, ensuring that the monks retained their lands. We do not know how Robert was contacted or how he managed to send his letter to Normandy, but its survival shows that cross-Channel communication was still both possible and effective. Yet in time, the rupture of the link between the Valognes family and its Norman lands proved troublesome, and at a later date, the monks appear to have had recourse to that most traditional of solutions, the forged charter.

The Bures documents cast an intriguing light upon the processes by which the Capetian régime took root in the localities of Normandy. A Capetian bailli relied upon an English baron to resolve a legal dispute in his bailliage, at a time when the kings of France and England were notionally at war. The documents show that the new régime could be responsive to local conditions, rather than always imposing French royal power in a brutal or high-handed fashion. The Bures deeds also reveal how an Anglo-Norman magnate, one whose continental interests have never even been noticed before, was in touch with his former Norman lands in the years when the long-established ties between England and Normandy were unravelling.

There is a postscript to Robert fitzWalter's letter to the French baillis. In 1212, he was identified as a ringleader in the plot to assassinate King John. His guilt seemed certain, for he fled to France and to the court of Philip Augustus. Did his previous contact with French officials in Normandy influence his choice of destination, or ease his passage there ${ }^{66}$ ? Such a question cannot be answered; but the Bures documents give us a rare glimpse of the impact of the loss of Normandy upon local Norman society in the years after King John and much of the Anglo-Norman baronage fled from the duchy.

66. Holt, 1961, p. 82, p. 88; MiCHel, Histoire des ducs de Normandie, p. 119-121, which says that Robert's flight took him first to Arras, then to the French court. 


\section{Bibliography}

Arnoux, Mathieu and Maneuvrier, Christophe, «Deux abbayes de Basse-Normandie: Notre-Dame du Val et le Val Richer (XII - -XIII siècles)», Le Pays Bas-Normand, 93, 2000, p. 1-111.

BAILdon, William Paley (ed.), Select Civil Pleas AD 1200-1203, London, Selden Society, 1890.

BALdwin, John W. (ed.), Les Registres de Philippe Auguste, Paris, Imprimerie nationale, Diffusion de Boccard, 1992.

BARrow, Geoffrey Wallis Stewart (ed.), Acts of William I, King of Scots 1165-24, Regesta Regum Scottorum, II, Edinburgh, Edinburgh University Press, 1971.

Barrow, Julia (ed.), Fasti Ecclesiae Anglicanae, Hereford 1066-130o, London, Athlone Press, 2002.

Calendar of Kent feet of fines to the end of Henry III's reign, CHURCHILL, Irene J. et al. (ed.), Ashford, Kent Archaeo. Soc., Records Branch, 1956.

Cartulaire de l'abbaye cistercienne de Fontaine-Daniel, Albert Grosse-Duperon and Émile Gouvrion (ed.), Mayenne, Poirier Béalu, 1896.

Chibnall, Marjorie (ed.), The Ecclesiastical History of Orderic Vitalis, 6 vols, Oxford, Oxford University Press, 1969-1980.

Complete Peerage of England, Scotland, Ireland, Great Britain and the United Kingdom, Vicary GibBs et al. (ed.), 13 vols in 14, London, St. Catherine Press, 1910-1959.

Curia Regis Rolls, Richard I - Henry III, 20 vols to date, London, HMSO, 1922.

Delisle, Léopold (ed.), Catalogue des actes de Philippe Auguste, roi de France, Paris, A. Durand, 1856

Delisle, Léopold (ed.), Recueil des Jugements de l'Échiquier de Normandie au XIII siècle, Paris, Imprimerie impériale, 1864.

English, Barbara, The Lords of Holderness 1086-1260, Oxford, Oxford University Press, 1979.

FArrer, William, Honors and Knights' Fees, 3 vols, London and Manchester, 1923-1925.

Fasti Ecclesiae Gallicanae, 7, (Diocèse d'Angers), Jean-Michel MATZ and François Comte (ed.), Turnhout, Brepols, 2003.

Fawtier, Robert (ed.), Registres du Trésor des Chartes, 3 vols, Paris, Archives nationales, 1958-1978.

Fowler, George Herbert (ed.), Cartulary of the Abbey of Old Wardon, Aspley Guise, Bedfordshire Historical Record Society, 1930.

Franklin, Michael J. (ed.), The Cartulary of Daventry Priory, Northampton, Northamptonshire Record Society, 1988.

Gallia Christiana, Dionysii Sammarthani et al. (ed.), 17 vols, Paris, 1715-1865.

Hall, George Derek Gordon (ed.), The treatise on the laws and customs of the realm of England commonly called Glanvill, $2^{\text {nd }}$ ed., Oxford, Oxford University Press, 1993.

Hall, Hubert (ed.), Red Book of the Exchequer, 3 vols, London, Rolls Series, 1896.

HARDy, Thomas Duffus (ed.), Rotuli litterarum patentium in turri Londinensi asservati, London, Record Commission, 1835. 
Hardy, Thomas Duffus (ed.), Rotuli Normannice in turri Londinensi asservati, Johanne et Henrico quinto Angliae regibus, London, Record Commission, 1835.

Hardy, Thomas Duffus (ed.), Rotuli de oblatis et finibus in turri Londinensi asservati, London, Record Commission, 1835.

HARdy, Thomas Duffus (ed.), Rotuli chartarum in turri Londinensi asservati (1199-1216), Record Commission, London, Record Commission, 1837.

HARdy, Thomas Duffus (ed.), Rotuli litterarum clausarum in turre Londinensi asservati, 2 vols, London, Record Commission, 1833-1844.

History of William Marshal, Anthony J. Holden (ed.), trans. Stewart Gregory, notes by David Crouch, 2 vols to date, London, Anglo-Norman Texts Society, 2002-2004.

Holt, James Clarke, The Northerners, Oxford, Oxford University Press, 1961.

HoLt, James Clarke, "Feudal society and the family in early medieval England. III. Patronage and Politics », Transactions of the Royal Historical Society, $5^{\text {th }}$ ser., xxxiii, 1984, p. 1-25.

Holt, James Clarke, Magna Carta, 2nd ed., Cambridge, Cambridge University Press, 1992.

Holt, James Clarke, Colonial England 1066-1215, London, Hambledon, 1997.

Keats-Rohan, Katharine Stephanie Benedicta (ed.), Domesday Descendants. A prosopography of persons occurring in English documents 1066-1166: II (Pipe Rolls to Cartae Baronum), Woodbridge, Boydell Press, 2002.

Liber Feudorum. The Book of Fees commonly called Testa de Nevill, 3 vols, London, PRO, 1920-31.

LuARD, Henry Richard (ed.), Annales Monastici, 5 vols, London, Roll Series, 1864-1869.

Maitland, Frederic William (ed.), Bracton's Note-Book, 3 vols, London, C.J. Clay and sons, 1887.

Meyer, Paul (ed.), Histoire de Guillaume le Maréchal, 3 vols, Paris, Société de l'Histoire de France, 1891-1894.

Michel, Francisque (ed.), Histoire des ducs de Normandie et des rois d'Angleterre, Paris, Société de l'Histoire de France, 1840.

Moore, Tony K., "The Rotulus de Valore Terrarum Normannorum and the invention of the "lands of the Normans" ", English Historical Review, vol. 125, 2010, p. 1071-1109.

Morgan, Marjorie, The English manors of the abbey of Bec, Oxford, Oxford University Press, 1946.

Nortier, Michel, «Un rôle des biens tombés en la main du roi en la baillie de Lisieux après la conquête de la Normandie par Philippe Auguste», Annales de Normandie, vol. 45, 1995, p. 55-68.

PAINTER, Sidney, The reign of King John, Baltimore, John Hopkins Press, 1949.

Palgrave, Francis (ed.), Rotuli Curice Regis, 2 vols, London, Record Commission, 1835.

PARIS, Matthew, Chronica Majora, ii, Henry Richard LuARD (ed.), 7 vols, London, Rolls Series, 1872-1873.

The Great Roll of the Pipe for the Second Year of the Reign of King John, Michaelmas 1200, ed. Doris M. Stenton, London, Pipe Roll Society, 1934. 
The Great Roll of the Pipe for the Sixth Year of the Reign of King Richard I, Michaelmas 1194, ed. Doris M. Stenton, London, Pipe Roll Society, 1928.

The Great Roll of the Pipe for the Tenth Year of the Reign of King Richard I, Michaelmas 1198, ed. Doris M. STEnTon, London, Pipe Roll Society, 1932.

Pollock, Frederick and Maitland, Frederic William, The History of English Law, ed. S.F.C. Milsom ( $2^{\text {nd }}$ ed.), 2 vols, Cambridge, Cambridge University Press, 1968.

Power, Daniel, «Between the Angevin and Capetian courts: John de Rouvray and the knights of the Pays de Bray, 1180-1225", Family Trees and the Roots of Politics: the Prosopography of Britain and France from the Tenth to the Twelfth Century, Woodbridge, Boydell Press, 1997, p. 361-384.

Power, Daniel, «King John and the Norman aristocracy», King John: New Interpretations, ed. S.D. Church, Woodbridge, Boydell Press, 1999, p. 117-136.

Power, Daniel, "The end of Angevin Normandy: the revolt at Alençon (1203)», Historical Research, 74, 2001, p. 444-464.

Power, Daniel, “"Terra regis Anglie et terra Normannorum sibi invicem adversantur”: les héritages anglo-normands entre 1204 et 1244", La Normandie et l'Angleterre au Moyen Âge, Pierre Bouet and Véronique Gazeau (ed.), Caen, Publications du CRAHM, 2003a, p. 189-209.

Power, Daniel, «The French interests of the Marshal earls of Striguil and Pembroke, 1189-1234", Anglo-Norman Studies XXV, John Gillingham (ed.), Woodbridge, Boydell Press, 2003b, p. 199-224.

Power, Daniel, The Norman frontier in the twelfth and early thirteenth centuries, Cambridge, Cambridge University Press, 2004.

Power, Daniel, «The Treaty of Paris (1259) and the aristocracy of England and Normandy", Thirteenth-Century England XIII, Janet Burton, Frédérique LaCHaud, and Phillippillipph Schofield (ed.), Woodbridge, Boydell Press, 2011, p. 141-157.

Powicke, Frederick Maurice, The Loss of Normandy 1189-1204: studies in the history of the Angevin Empire, $2^{\text {nd }}$ ed., Manchester, Manchester University Press, 1961.

Ramackers, Johannes (ed.), Papsturkunden in Frankreich, Neue Folge. 2. Band: Normandie, Göttingen, Vandenhoeck and Ruprecht, 1937.

Recueil des actes de Philippe Auguste, roi de France, Delaborde, Henri-François, et al. (ed.), 6 vols, Paris, 1916-2006.

Recueil des Historiens des Gaules et de la France, M. Bouquet et al. (ed.), 24 vols, Paris, Imprimerie Nationale, 1738-1904.

Richardson, Henry Gerald, «A Norman lawsuit», Speculum, 7, 1932, p. 383-392.

Richardson, Henry Gerald (ed.), The Memoranda Roll for the Michaelmas Term of the First Year of the Reign of King John (1199-1200), London, Pipe Roll Society, n.s. xxi, 1943 .

Riley, Henry Thomas (ed.), Gesta Abbatum Monasterii Sancti Albani, 3 vols, London, Rolls Series, 1867-1869.

Round, John Horace, «Walter Tirel and his wife», Feudal England, London, S. Sonnenschein, 1895, p. 355-363.

Round, John Horace, «The Fitzwalter pedigree», Transactions of the Essex Archaeological Society, n.s. 7, 1900, p. 329-330. 
Round, John Horace, «King John and Robert Fitzwalter», English Historical Review, 19, 1904a, p. 707-711.

Round, John Horace, «Comyn and Valognes», The Ancestor, 11, 1904b, p. 29-35.

Round, John Horace (ed.), Rotuli de dominabus et pueris et puellis de XII comitatibus [1185], London, Pipe Roll Society, 1913.

Rymer, Thomas (ed.), Fodera, conventiones, litterae et cujuscunque generis acta publica, new ed., London, Record Commission, 1816.

SAlter, Herbert Edward (ed.), The feet of fines for Oxfordshire 1195-1291, Oxford, Oxfordshire Rec. Soc., 1930.

SAlter, Herbert Edward (ed.), The Thame Cartulary, 2 vols, Oxford, Oxfordshire Rec. Soc., 1947-1948.

SANDERS, Ivor John, English baronies: a study of their origin and descent (1086-1327), Oxford, Oxford University Press, 1960.

Stevenson, Joseph (ed.), Radulphi de Coggeshall Chronicon Anglicanum, London, Rolls Series, 1875.

Stevenson, Wendy B., England and Normandy, 1204-59, unpubl. Ph.D. diss., University of Leeds, 1974.

Stringer, Keith, «Philip de Valognes (d. 1215)», Oxford Dictionary of National Biography, Henry Colin Matthew and Brian Harrison (ed.), 6o vols, Oxford, Oxford University Press, 2004, lvi, p. 66-67.

Teulet, Alexandre (ed.), Layettes du Trésor des Chartes, 5 vols, Paris, Plon, 1863-1909.

Thомpson, Kathleen, "L'aristocratie anglo-normande et 1204 ", La Normandie et l'Angleterre au Moyen Âge, Pierre Bouet and Véronique Gazeau (ed.), Caen, Publications du CRAHM, 2003, p. 179-187.

Trotter, David, "(Socio) linguistic realities of language contact across the Channel in the Thirteenth Century», Thirteenth-Century England XIII, Janet BurTon, Frédérique Lachaud and Phillipp Schofield (ed.), Boydell Press, Woodbridge, 2011, p. 117-31.

Victoria History of the County of Bedford, 3 vols, London, Constable, 1904-14.

Victoria History of the County of Essex, 10 vols, London, Constable, and Oxford, Oxford University Press, 1903-2001.

Victoria History of the County of Hertford, 4 vols, London, Constable and St Catherine Press, 1902-1923.

Victoria History of the County of Northampton, 6 vols, London, Constable and St Catherine Press; Oxford, Oxford University Press; and Woodbridge, Boydell Press, 1902-2007.

Victoria History of the County of Oxford, 15 vols, London, Constable, and Woodbridge, Boydell Press, 1907-2006.

Victoria History of the County of Warwick, 9 vols, London, Constable, 1904-1969.

Vincent Nicholas, «King Henry II and the Poitevins», La cour Plantagenêt (1154-1204), ed. Martin Aurell, Poitiers, CESCM, 2000, p. 103-137.

Warlop, Ernest, The Flemish nobility before 130o, 2 vols in 4, Kortrijk, G. DesmetHuysman, 1975-1976. 


\section{Appendix I: acts concerning the fief of Valognes at Bures, 1190-1209}

The following sequence of documents concerning the fief of Gunnor de Valognes at Bures-en-Bray allow us to reconstruct the events between 1190 and 1208. The liasse 20 HP 6 from the Archives de la Seine-Maritime includes seven acts that are tied together, in the following order: an act of 1302 (see above, n. 64), followed by the charters below, in the order $\mathrm{n}^{\circ} 7,5,4,2,3,1$. This common preservation appears to date from the Middle Ages, and the endorsements suggest that the first five were kept together from the late thirteenth century or early fourteenth century onwards (and possibly $n^{\circ} 7$ as well). The other acts published below come from the liasse 20 HP 1 ( $\left.n^{\circ} 8-9\right)$ or from a register of Philip VI ( $\left.n^{\circ} 6\right)$.

In the editions below, punctuation and capitalisation have been modernised; for extensions of abbreviations, only proper names are indicated, in curved brackets. For the original acts from the liasses of the Archives de la SeineMaritime, textual variants from the later register copy of the vidimus of 1347 have not been indicated. $\mathrm{N}^{\circ}$ 1-5 and 7-9 are published here by permission of the Archives de la Seine-Maritime, Rouen, and $n^{\circ} 6$ with the permission of the Archives nationales, Paris.

\section{No 1}

Durand de Hostilli and his wife Gunnor, daughter and heiress of Robert de Valognes, grant all their land at Bures-en-Bray of the fief of Valognes, for the souls of Robert and Hawise de Valognes and others, to Notre-Dame-du-Pré, in return for 10 livres angevins per annum (1190).

A. Original act: Rouen, Arch. dép. Seine-Maritime, 20 HP 6.

$B$. Vidimus (1347) from $A$ : lost.

C. Copy (1347) from B, Trésor des Chartes, Register LXVIII: Paris, Arch. nat., JJ 68 , fol. $473 \mathrm{r}^{67}$.

Edited from $A$.

$218 \mathrm{~mm}$ across $x 185 \mathrm{~mm}$ down (folded). Slits and parchment tags for two seals; the right seal is lost, but a large portion of the left one survives (a fragment $40 \mathrm{~mm}$ down $\times 35 \mathrm{~mm}$ across). Its obverse bears a shield charged with a lion rampant, and its reverse contains the imprint of a small counterseal depicting a perching bird facing sinister, towards a plant.

Late-twelfth-century hand.

Durandus de Hostilli et uxor sua Gunnor, filia Rob(er)ti de Valunnes et heres, omnibus ad quos presens scriptum pervenerit, salutem. Sciatis nos et heredes nostri dedisse et hac carta nostra confirmasse Deo et ecclesie Sancte Marie

67. Cf. Fawtier, Registres du Trésor des Chartes, iii, $\mathrm{n}^{\circ}$ 2619. Philip VI confirmed all the acts published here except $n^{\circ} 5$, for which his act contained an alternative version $\left(n^{\circ} 6\right)$. Philip also confirmed acts of Henry II for Notre-Dame du Pré and Philip Augustus for Bec. Minor variations in orthography between the originals and the Trésor des Chartes copies have been omitted here. 
de Pratis ${ }^{68}$ Rothomagi et monachis ibidem Deo servientibus, pro animabus antecessorum nostrorum et maxime pro anima Rob(er)ti de Valunnes et Hawisie de Valunnes et Gaufridi Dier' et Tephanie, totam terram nostram de Bures de feudo de Valunnes cum mainillo et bosco et pratis et pascuis et omnibus ad predictam terram pertinentibus, perpetuo, libere et quiete tenendam et possidendam, reddendo nobis sive heredibus nostris decem libras andegavensium annuatim ad festum sancti Cristophori ${ }^{69}$ apud Hostilli, nullam penitus mundialem exactionem de predicta terra sive de hominibus terram prenominatam tenentibus requirentes. Pro ista vero concessione a prescriptis monachis de caritate ecclesie sue CL libras andegavensium recepimus. Sciendum est etiam quod monachi prenominati primos tredecim annos post primam coronationem domini Ricardi regis Anglie hanc predictam terram quietam et absque omni redditu solutam habebunt et tenebunt. Post finem vero predictorum tredecim annorum termino prescripto nobis annuatim decem libras andeg(avensium) reddent. Et ut concessio ista rata et inconcussa permaneat, appositione sigillorum nostrorum cartam istam munivimus. Concessio autem ista facta fuit anno ab incarnatione Domini . M ${ }^{\circ}$.C.XC. consilio et peticione domini Philippi de Valunnes $^{70}$ et Johannis clerici de Valunnes ${ }^{71}$. Hujus conventionis hii sunt testes: Rad(ulfus) de Lattun'72, Gilb(ertus) de Hostelli, Mazi de Funteneill', Hug(o) Wiscard, Rog(erus) de Furneus, Gervasius de Tiwinge ${ }^{73}$, Oliver de Lanvale $^{74}$, Rad(ulfus) filius Pagani, Ric(ardus) Aguillun, Walt(erus) de Westl', Walt(erus) de Funteneill', Rog(erus) de Lattun', Alexand(rus) de Tiwinge, Reginald(us) de Meneres $^{75}$, Will(elmus) de Turpes, Math(eu)s de Bures, Godefrid(us) de Bures, Will(elmus) Pinel, Augustinus de Evermu ${ }^{76}$, Ricard(us) le Marescal ${ }^{77}$.

Notes on verso as follows:

(i) Carta Durandi de Osteilli et Gunnor de Valunneis ${ }^{78}$ (early $13^{\text {th }}$ century).

68. Sic.

69. 25 July, usually identified as the feast of St James (the Great).

70. Gunnor's paternal uncle, younger brother of her father Robert, who benefited from the patronage of William the Lion to become chamberlain of Scotland and a great landowner there, and whose granddaughters inherited the Valognes lands in England in 1232 upon the extinction of Gunnor's descendants.

71. Possibly another paternal uncle of Gunnor?

72. Ralph of Latton (Essex) held a fief of the honour of Valognes at Latton between 1184 and 1201, and appears as Robert fitzWalter's man in 1198; in 1208 Robert was seeking custody of Ralph's heir (P.R. 9 Richard I, p. 135; VCH Essex, viii, p. 188; Curia Regis Rolls, v, p. 223).

73. Probably Tewin (Herts.), which formed part of the Valognes barony (VCH Herts., iii, 481-482). In 1200 a case concerning Tewin was heard in Robert fitzWalter's court (Curia Regis Rolls, i, p. 169).

74. Oliver, Sic. Perhaps a member of the important Anglo-Breton family of Lanvallay, which was prominent in Essex and Herts. William III de Lanvallay, lord of Walkern (Herts.) and constable of Colchester, married Robert fitzWalter's niece Matilda Pecche (Sanders, 196o, p. 92, p. 48).

75. Perhaps Mesnières-en-Bray (Seine-Maritime, cant. Neufchâtel-en-Bray).

76. Sic. Envermeu (Seine-Maritime, ar. Dieppe, ch.-lieu de cant.).

77. Perhaps the marshal of the abbey of Jumièges of that name (e.g. Rouen, Arch. dép. SeineMaritime, $9 \mathrm{H} \mathrm{4}$, p. $183 \mathrm{n}^{\circ}$ 302: act of Richard marescallus, his wife Denise, and their son Aubin, concerning the feodum mareschaucie at Jumièges, 17 Dec. 1212).

78. Sic. 
(ii) Carta Gonnor de Valongnes de feodo de Valoignes apud Bures (late $13^{\text {th }}$ or early $14^{\text {th }}$ century).

(iii) $t\left(\right.$ i)t(ulus) de Buris iii $^{c}$ lxviii. (15 ${ }^{\text {th }}$ century: apparently a reference to a lost cartulary).

(iv) Bures (16 ${ }^{\text {th }}$ century).

\section{No 2}

Robert fitzWalter grants to Notre-Dame-du-Pré all the land of the fief of Valognes at Bures, from the inheritance of his wife Gunnor, for 10 livres angevins per annum, as Gunnor granted it before their marriage (s.d., $1194 \times 1202)$.

A. Original act: Rouen, Arch. dép. Seine-Maritime, 20 HP 6.

$B$. Vidimus (1347) from $A$ : lost.

C. Copy (1347) from B, Trésor des Chartes, Register vol. LXVIII (1347): Paris, Arch. nat., JJ 68, fols 473-v.

\section{Edited from $A$.}

Late $12^{\text {th }}$-century or early $13^{\text {th }}$-century hand; $218 \mathrm{~mm}$ across $x 110 \mathrm{~mm}$ down (with deep fold); slits andtag for lost seal.

Sciant presentes et futuri quod ego Robertus filius Galteri concessi et hac carta mea confirmavi Deo et ecclesie Sancte Marie de Prato Rothomagi et monachis ibidem Deo servientibus totam illam terram que est de feodo de Valoines apud Bures, de hereditate Gunnor uxoris mee, cum menillo et pratis et pascuis et cum omnibus ad eandem terram pertinentibus, habendam et tenendam eisdem monachis de me et de heredibus meis bene et in pace, libere, quiete, integer, finabiliter, reddendo inde annuatim mihi vel heredibus meis, pro omnibus serviciis et exactionibus et pro omnibus rebus, decem libras andegavensium ad festum sancti Christofori sine aliquibus occasionibus, sicut predicta Gunnor uxor mea, antequam mihi matrimonio copularetur, concesserat et carta sua confirmaverat. Hanc autem terram predictam cum omnibus pertinenciis suis, ego Robertus predictus et heredes mei finabiliter warantizabimus predictis monachis contra omnes gentes per predictum servicium. Et quia volui hanc concessionem et hujus carte mee confirmationem ratam et stabile et inconcussam haberi, eam sigillo meo roboravi. Hiis testibus Will(elm)o fil(io) Galt(er)I $\mathrm{I}^{79}$, Hug(one) de Hastinges, Henr(ico) de Laune ${ }^{80}$, Sym(one) fil(io) Walteri ${ }^{81}$, Thom(a) Mercerio, Ric(ardo) de $\operatorname{Hosde}(n) g^{82}$, Rad(ulfo) de Furcis, Rob(erto) de Sancto Albano.

79. Either Robert fitzWalter's steward of this name (Curia Regis Rolls, i, p. 291, p. 450), or Robert's brother William, archdeacon of Hereford, who shared Robert's exile in 1212 (HARDY, Rotuli Litterarum Clausarum, i, p. 165-166; HARDY, Rotuli patentium, p. 101; BARRow, Fasti Ecclesiae Anglicanae, p. 24).

80. Henry de Alneto was one of those exiled with Robert fitzWalter in 1212: Hardy, Rotuli clausarum, i, p. 165-166.

81. Possibly Robert fitzWalter's half-brother Simon, lord of Daventry (Northants.), for whom see above, n. 30.

82. Possibly Hodeng (Seine-Maritime, cant. Neufchâtel-en-Bray, c. Nesle-Hodeng). 
verso:

(i) Tempore prioris J. de Castell'. ( $13^{\text {th }}$ century).

(ii) Carta Rob(er)ti Galt(er) $i^{83}$ de feodo de Valoignes apud Bures (late $13^{\text {th }}$ or early $14^{\text {th }}$ century).

(iii) $t$ (i)t(ulus) de Buris $\mathrm{iii}^{c} \mathrm{iii}^{x x} v\left(15^{\text {th }}\right.$ century: cross-reference to lost cartulary).

\section{$\mathrm{No}^{\circ} 3$}

Gunnor, daughter of Robert de Valognes, confirms her grant of Bures to the monks of Notre-Dame du Pré, stipulating that it is for the sake of the soul of Richard de Mountfichet, a kinsman of her husband Robert fitzWalter. She has reduced the charge upon the land to 1oos., and the monks are to pay this pension to Gerard, prévôt of Gournay, and his son Odo, to whom her husband Robert fitzWalter has granted this revenue for life in return for their service (1202).

A. Original act: Rouen, Arch. dép. Seine-Maritime, 20 HP 6.

$B$. Vidimus (1347) from $A$ : lost.

C. Copy (1347) from B, Trésor des Chartes, Register vol. LXVIII: Paris, Arch. nat., JJ 68, fol. $473 \mathrm{v}$.

Edited from $A$.

$177 \mathrm{~mm}$ across $x 215 \mathrm{~mm}$ down (folded); tags and slits for lost seal. Late $12^{\text {th }}$-century or early $13^{\text {th }}$-century hand.

Sciant presentes et futuri quod ego Gunnor, filia Rob(er)ti de Valu(n)gnes et heres, concessi et hac mea carta confirmavi, pro salute mea et omnium antecessorum meorum et pro anima Ricardi de Montfichet cognati Rob(erti) filii Gualt(eri) mariti mei, Deo et ecclesie Sancte Marie de Prato Roth(omagi) et monachis ibidem Deo servientibus totam terram quam jure hereditario apud Bures possidebam de feodo de Valu(n)gnes cum mainillo et bosco et pratis et pascuis et omnibus ad predictam terram pertinentibus, perpetuo tenendam et ut propriam possidendam in puram et perpetuam elemosinam, ita liberam et quietam ut ego aut heredes mei in ea nichil omnino decetero possimus reclamare, pro centum solidis andegavensium annui redditus. Predicti autem monachi istos centum solidos Girardo preposito de Gornaio vel Odoni filio ejus singulis annis ad festum sancti Remigii quamdiu vixerint reddent quos eis $\mathrm{R}$ (obertus), dominus meus, assensu et voluntate mea, pro servitio suo contulit. Post decessum vero illorum prefati, monachi prefatos centum solidos mihi vel heredibus meis absque ullo impedimento solvere tenebuntur. Et ut hoc ratum et firmum futuris temporibus permaneat, presens scriptum sigilli mei appositione roboravi. Actum est hoc anno gratie. $\mathrm{M}^{\circ}$. $\mathrm{CC}^{\circ}$. $\mathrm{II}^{\circ}$. Testibus his Balduino comite

83. Sic. 
Albemalle $^{84}$, Toma de $\mathrm{Ver}^{85}$, Henrrico de Aneto ${ }^{86}$, Hais comitissa Albemalle ${ }^{87}$. Hugone de Bures, Godefrido Grosso, Ricardo Marescallo et multis aliis. verso:

(i) Carta Go(n)nor de Valo(n)gnes de hoc quod habebat apud Bures (late $13^{\text {th }}$ or early $14^{\text {th }}$ century).

(ii) $t(i) t(u l u s)$ de Buris $i i i^{x x} x i x\left(15^{\text {th }}\right.$ century: cross-reference to lost cartulary).

\section{$\mathrm{N}^{\circ} 4$}

Robert fitzWalter announces that he has granted all that he had in the manor of Bures to the monks of Notre-Dame-du-Pré, for 1oos. currentis monete (June 1204 $x$ April 1208) ${ }^{88}$.

A. Original act: Rouen, Arch. dép. Seine-Maritime, 20 HP 6.

$B$. Vidimus (1347) from $A$ : lost.

C. Copy (1347) from B, Trésor des Chartes, Register vol. LXVIII: Paris, Arch. nat., JJ 68 , fol. $473 \mathrm{v}$.

Edited from $A$.

$140 \mathrm{~mm}$ across $x 50 \mathrm{~mm}$ down (left edge), $42 \mathrm{~mm}$ (right edge); letter close with fragment of tongue remaining. Early $13^{\text {th }}$-century hand.

Sciant omnes ballivi et servientes domini regis Gallie Archar(um) et Rothom(agi) quod ego Rob(ertus) filius Walt(er)i dedi et concessi et carta mea confirmavi in puram et perpetuam elemosinam liberam et quietam Deo et sancte Marie de Prato Rothom(agi) et monachis ibidem Deo servientibus quicquid habebam in manerio de Buris de feodo de Valunnes, pro centum solidis currentis monete annuatim reddendis mihi et heredibus meis, sicut carta mea testatur. Et ideo, si Girardus prepositus de Gornaco vel filius ejus vel quilibet alius trahunt predictos monachos in causam de dicta elemosina contra cartam meam, monachos injuste vexari noverint universi.

verso: Carta Roberti Galteri ${ }^{89}$ de feodo de Valoignes apud Bures (late $13^{\text {th }}$ or early $14^{\text {th }}$ century).

No $5-6$

Gerard, prévôt of Gournay, and his son Odo sell to the monks of Notre-Damedu-Pré the 10os. which the monks paid them annually at Bures, for 25 livres

84. Baldwin de Béthune (d. 1212), third husband of Hawise, countess of Aumale, and one of the best-known companions of William Marshal in the History of William Marshal. See WARLOP, 1975-1976, ii, I, p. 66o, p. 666; above, n. 46.

85. Presumably Thomas de Vere (d. 1204) of Great Addington (Northants.), head of a junior branch of the Vere earls of Oxford (VCH Northants, iii, p. 156-157).

86. Henrrico, Sic. Perhaps the same man as Henry de Launeo who witnessed $n^{\circ} 1$ above?

87. Hawise, countess of Aumale: see above, n. 46.

88. For the date of this act, see above, p. 12-14.

89. Sic. 
tournois, in the presence of John de Rouvray, castellan of Arques (1204 x c.1210 and 1208).

The following two acts (one original but damaged, the other a copy but intact) appear to relate to the same transaction, but they contain very different terms and distinct witness-lists.

\section{No 5}

A. Original act, Rouen, Arch. dép. Seine-Maritime, 20 HP 6: badly mutilated, so the exact terms cannot be known.

Edited from $A$.

110-158mm across (originally c. 200mm?) $\times 190 \mathrm{~mm}$ down (folded lower edge). About half the right-hand side of the act has been lost, with two matching triangles of parchment missing from the right-hand edge; there are also two pairs of matching holes in the centre of the manuscript, affecting lines 3 and 13 (of 16 lines). These show that the act was folded over when stored. Some of the missing words are suggested below in square brackets.

Tags and slits for two seals. The left seal is lost. A brown wax fragment of the right seal survives: its pointed top suggests that it was oval, which means that Odo may have been a clerk. The inscription is ' $\mathrm{S}$. ODON. [...]O'90; the obverse bears part of the figure of a beast statant, facing sinister, possibly a dog. Early $13^{\text {th }}$-century hand.

(1) Sciant omnes presentes et futuri quod ego Girardus prepositus de Gornaio, et $\mathrm{O}$ [do filius meus] [... / $^{(2)}$ monachis de Prato juxta Rothomagum [t]enere et possidere in perpetuum illos centum [solidos] [...] [...] [Rober-] / ${ }^{(3)}$ tus filius Walteri [...] $\mathrm{m}$ [...] elemosina pro anima Ricardi de M[onteficheto] [...] [... $]^{(4)}$ Bures de feodo de Valognes de quo annuatim reddere teneb[antur] [...] $[\ldots] /^{(5)}$ dederat pro nostro servitio quamdiu vixerimus habendas. et a predictis $\mathrm{m}$ [onachis] [...] / ${ }^{(6)}$ nobis fecerat predictos vero .centum. solidos redditus quos eis contulit volumus et conced[imus] [...] [habe-] / (7) ant et possideant libere et quiete et integre in perpetuum sicut carta testatur, quam id[em] [...] $[\ldots] /^{(8)}$ inde fecit, absque nostri decetero ulla reclamatione vel nostrorum disturbatione seu impedim[ento] [...] [...] / (9) sol'. redditus que nobis inde remanere debebant tota vita nostra eisdem monachis vend[idimus] [...] [...] / (10) pro $\mathrm{xxv}^{\text {que }}$ libris turonensium et super altare beate Marie in eadem ecclesia Prati illos obtul[imus] [...] [...] / ${ }^{(11)}$ sacrosancta nos decetero intoto ${ }^{91}$ prefato redditu nichil reclamare nec in prefatis [...] [...] / ${ }^{(12)}$ eis predictus miles nec in aliis centum solidis redditus quos eis vendidimu[s] [...] [ego Girardus et (?)] / ${ }^{(13)}$ predictus O. fil[ius me] us [...] [t] otam vitam nostram predict [...] [garanti-] / ${ }^{(14)}$ zare. Ut autem hoc firm[um] [...] [t]eneatur, sigillis nostris confirm [...] [...]

90. Presumably 'S. Odon. de Gornaco'.

91. Sic. 
[Johanne] / ${ }^{(15)}$ de Rovreio, tunc castellano Archar(um) anno gratie $\mathrm{M}^{\circ}\left[\mathrm{CC}^{\circ}\right]^{92}$ [...] [...] / (16) de Petravilla ${ }^{93}$, Rob(erto) de Crespeires, Nich(olao) de Montaine ${ }^{94}$, Wil[lelmo] $[\ldots]$

verso:

(i) Carta prepositi de Gornei Bur' (late $13^{\text {th }}$ or early $14^{\text {th }}$ century).

(ii) Bures (14 $4^{\text {th }}$ century).

(iii) $t$ (i)t(ulus) de Bures xlvii ( $15^{\text {th }}$ century: cross-reference to lost cartulary).

\section{No 6}

$A$. Original or purported original, lost.

$B$. Vidimus (1347) from $A$ : lost.

C. Copy (1347) from B, Trésor des Chartes, Register vol. LXVIII (1347): Paris, Arch. nat., JJ 68, fol. 473v.

Edited from $C$.

Sciant omnes presentes et futuri quod ego Girardus, prepositus Gornaii, et Odo filius meus vendidimus et omnino relinquimus ${ }^{95}$ pro viginti quinque libris turonensium monachis Sancte Marie de Prato Rothomagi centum solidos anui ${ }^{96}$ redditus monete currentis quos dederat nobis pro servicio nostro quamdiu vixerimus dominus Rob(ertus) filius Walt(er)i militis apud Bur(es) de feodo de Vall(ongnes) quos reddebant nobis predicti monachi singulis annis. Et ego et prefactus ${ }^{97}$ Odo filius meus prefactos ${ }^{98}$ centum solidos redditus super altare beate Marie in eadem ecclesia Prati coram conventu obtulimus. Juravimus eciam super sacrosancta nos de cetero nichil reclamare in predicto redditu, neque per nos neque per alios. Nos vero debemus predictis monachis predictos centum solidos per totam vitam nostram contra omnes gentes garantisare ${ }^{99}$. Et ut hoc ratum et firmum nostris temporibus permaneat, presens scriptum sigillorum nostrorum roboravimus. Actum fuit hoc coram domino Joh(ann)e de Rouvreyo, tunc castell(ano) Archarum et justic(iario) domini regis anno gratie millesimo $\mathrm{CC}^{\circ}$. VIII $^{\circ}$. Testibus hiis: Ric(ardo) Co(m)mni ${ }^{100}$, Joh(an)ne fratre suo, Pet(r)o de Novo

92. This must postdate the fall of Rouen in 1204 and predate John de Rouvray's renunciation of the castellanship of Arques (c.1210). Most probably it read '1208'.

93. In 1210 a Renaud de Pierreville issued an act for Fécamp concerning St-Ouen (Seine-Maritime, cant. Bellencombre, c. Crique) witnessed by John de Rouvray, 'tunc temporis iustic(iario) domini regis in Caleto' (Rouen, Bibl. Municipale, Y 51, fol. 65r).

94. Possibly Nicholas de Montagny (de Montegni), a Norman from the Andelle valley who benefited from the Capetian victory (Power, 2004, p. 278, p. 428).

95. Sic.

96. Sic.

97. Sic.

98. Sic.

99. Sic.

100. Sic. The original manuscript presumably read 'Co(m)min'. Rouen, Arch. dép. Seine-Maritime, 20 HP 6, also contains an act of Richard Comin, son of Bernard Comin, confirming the grant of his mother Hawise to Notre-Dame-du-Pré at Chareuilla or Caruilla (c.1200). 
M(er)catu ${ }^{101}$, Roberto Avenar', Pet(r)o G(r)ameth, Ric(ardo) de Eskekevill(a) ${ }^{102}$, Godeffr(ido) ${ }^{103}$ Grosso, Ric(ardo) Marescall(o) ${ }^{104}$, Haudenn' Cogno, Joh(an)ne Thorco Hug(one) Pisc' et multis aliis.

\section{No 7}

John de Rouvray, castellan of Arques, announces the agreement between NotreDame-du-Pré and Gerard, prévôt of Gournay, and his son Odo, concerning the gift of Robert fitzWalter (Rouen, $6 \times 30$ April) ${ }^{105}$.

A. Original act: Rouen, Arch. dép. Seine-Maritime, 20 HP 6.

$B$. Vidimus (1347) from $A$ : lost.

C. Copy (1347) from $B$, Trésor des Chartes, Register vol. LXVIII (1347): Paris, Arch. nat., JJ 68, fol. 473v.

Edited from $A$.

225mm across $x$ 62-69mm down (including fold); slits and tag for lost seal. Early - I mid-thirteenth century hand; minor surface damage.

Omnibus ad quos presens scriptum pervenerit, Joh(annes) de Rovreio tunc castellanus Archar(um) salutem. Noveritis me testem esse de conventione facta inter monacos ${ }^{106}$ Sancte Marie de Prato Rothomagi et Girardum prepositum de Gornai et Odon(em) filium eius de quodam redditu apud Bures de feodo de Valognes quem ibi habebant de dono Rob(er)ti fil(ii) Walt(er)i. possidend(um) tota vita sua, quem scilicet predicti Gir(ardus) et Odo jamdictis monachis vendiderunt pro XXV. libris turonensium et debent garantizare qua[m]diu vixerint eisdem monachis sicut carta inde inter eos facta testatur. Et in hujus rei testimonium, presens scriptum sigillo meo confirmari feci, apud Roth(omagum), anno gratie M CC octavo, mense aprili.

verso:

(i) Tempore prioris .J. de Castell' $\left(13^{\text {th }} \mathrm{C}\right.$.)

(ii) Bures $\left(13^{\text {th }}\right.$ C.?)

(iii) Littera Castellani de Archis de vendicione feod' de Vallongnes (late $14^{\text {th }}$ or early $15^{\text {th }}$ century)

\section{No 8}

Gunnor, daughter and heiress of Robert de Valognes, 'widow' of Robert fitzWalter, grants 10os. angevins (sic) from the fief of Valognes to the monks of Bec at NotreDame-du-Pré (1209) (spurious act).

101. Neuf-Marché (Seine-Maritime, cant. Gournay).

102. Équiqueville (Seine-Maritime, cant. Envermeu, c. St-Vaast-d'Équiqueville).

103. Sic.

104. See n. 77 above.

105. This dating assumes that the year was determined by the Capetian custom, namely by Easter (6 April 1208; in 1209 Easter fell on 29 March, so the act cannot refer to April 1209). 106. Sic. 
For the reasons why this act cannot be authentic, see above p. 14-16.

$A$. Spurious sealed original, late $13^{\text {th }}$ or early $14^{\text {th }}$ century, Arch. dép. SeineMaritime, $20 \mathrm{HP} 1$.

$B$. Vidimus (1347) from $A$ : lost.

C. Copy (1347) from $B$, Trésor des Chartes, Register vol. LXVIII: Paris, Arch. nat., JJ 68 , fol. $473 \mathrm{v}$.

Edited from $A$.

$178 \mathrm{~mm}$ across $x 152 \mathrm{~mm}$ down (folded); slit and parchment tags for fragment of dark brown seal (c.18mm across $x 20 \mathrm{~mm}$ down), which depicts two clasped hands (the principal image on the seal). Imitative hand, perhaps early fourteenth century.

Notum sit omnibus tam presentibus quam futuris quod ego $\mathrm{Gu}(\mathrm{n})$ nor, filia Roberti de Valu(n)gnes et heres, relicta condam Rob(er)ti filii Galt(er)i, dedi et concessi et omnino dimisi in puram et perpetuam elemosinam Deo et ecclesie Sancte Marie de Prato juxta Rothomagum et monachis Beccensibus ibi Deo servientibus centum solidos andegavensium annui redditus pro salute anime mee et omnium antecessorum meorum, quos habebam super feodum de Valungnes cum mainillo et bosco et pratis et pascuis et omnibus ejusdem terre pertinenciis in territorio de Buris, quos Rob(er)t(us) filius Galt(er)i, maritus meus, condam de voluntate mea et concensu ${ }^{107}$ contulit Girardo preposito de Gornaio et Odoni ejusdem filio pro suo servicio quamdiu predicti vixerint, qui centum solidi debent ad me et heredes meos post mortem ipsorum revenire, quos centum solidos predicti monachi tenebuntur persolvere eisdem toto tempore quo predicti vixerint ad festum beati Remigii, tenendos et habendos predictis monachis bene, pacifice et quiete, absque mei vel heredum meorum in predictis centum solidis reclamatione decetero facienda. Et sciendum est quod predicti monachi de curialitate ${ }^{108}$ sua michi dederunt quindecim libras andegavensium. Et ut hoc ratum et stabile pro tempore futuro. ego predicta $\mathrm{Gu}(\mathrm{n})$ nor presentem cartam sigilli mei munimine roboravi. Actum fuit anno Domini $\mathrm{M}^{\circ} \mathrm{CC}^{\circ}$ nono. Testibus hiis Tho(m)a de Ver ${ }^{109}$, Hugone de Bures, Ricardo Marescal, Vill(elm)o de Bures preposito de Bures, Vill(elm)o de Haia, Gaufrido le Gros, Reginaldo de Meneres, Vill(elm)o de Tourpes, Augustino de Evremeu et pluribus aliis verso:

(i) Carta Rob(ert)i filii Galt(er)i pro centum sol(idis) (1 $4^{\text {th }}$ century)

(ii) de Valognes a Bur' ( $15^{\text {th }}$ century)

(iii) $t$ (i)t(ulus) de buris $i i i^{c} l x x v$ ( $15^{\text {th }}$ century: cross-reference to lost cartulary)

(iv) Bures $\left(16^{\text {th }} \mathrm{C}\right.$. ?)

107. Sic.

108. Sic.

109. Thomas de Vere of Great Addington had died in 1204 (HARDy, Rotuli clausarum, i, p. 10). 


\section{No 9}

Inventory of deeds concerning the Valognes fief at Bures ( $15^{\text {th }}$ century).

A. Early $15^{\text {th }}$-century list, Arch. dép. Seine-Maritime, 20 HP 1.

Edited from $A$.

Unsealed, unfolded single sheet of parchment, 235 $\mathrm{mm}$ across $x 115 \mathrm{~mm}$ down. Early $15^{\text {th }}$-century hand.

... Durandus de Hostelli et Gonnor lejus uxor $/{ }^{110}$, filia Rob(er)ti de Valloignes et heres, ecclesie Beate Marie de Prato et monachis ibidem Deo servientibus dederunt totam terram quam habebant in Bur(is) de feodo de Valloignes, pro decem libris andegavencium ${ }^{111}$ eisdem annuatim reddis ${ }^{112}$, quibus de curialitate Isua/ ${ }^{113}$ dederunt centum et quinquaginta libras andegavensium. [ $\left.\mathrm{n}^{\circ} 1\right]$

g Rob(er)tus filius Galt(er)i hanc dationem confirmavit, qui fuit secundus maritus ejusdem Gonnorre ${ }^{114}$. [ $\left.\mathrm{n}^{\mathrm{o}} 2\right]$

g Gonnor, filia Rob(er)ti de Valloignes, omnem territorium suum de Bur(is) de feodo de Valloignes quod possidebat dedit dictis religiosis pro centum solidis quos tenebantur annuatim Girardo preposito de Gournayo reddere quamdiu vita eis esset comes ${ }^{115}$. [ $\left.\mathrm{n}^{\mathrm{o}} 3\right]$

g Robertus filius Galteri confirmavit et dedit predictos centum solidos dictis religiosis perpetuis temporibus possidendos. [n $\left.{ }^{\circ} 4\right]$

g Girardus prepositus de Gournaco ${ }^{116}$ et Odo filius suus vendiderunt dictis religiosis dictos centum solidos quos eisdem tenebantur annuatim reddere. [ $\mathrm{n}^{\circ}$ 5 or $\left.\mathrm{n}^{\circ} 6\right]$

g J. de Rouvreyo, castellanus Archar(um), per litteras suas de hoc perhibet testimonium [n $\mathrm{n}^{\circ}$ ]

g Gonnor predicta, cujus erat dicta hereditas mortuo ejus marito, eisdem religiosis dedit dictos centum solidos ad se tanquam propriam heredem devolutos mortuis dictis Girardo et Odone ejus filio cui de curialitate sua dederunt XV libras andegavensium. [no 8 ]

Verso: Ordo litterarum de Valognes ( $15^{\text {th }}$ century).

\footnotetext{
110. 'eius uxor' above the line.

111. Sic.

112. Sic.

113. 'dictorum relig(iosorum)' has been deleted and replaced with 'sua' above the line.

114. Sic.

115. Sic.

116. Sic.
} 


\section{Appendix II: Genealogical Tables}

\section{Table I: the family of Valognes ${ }^{117}$}

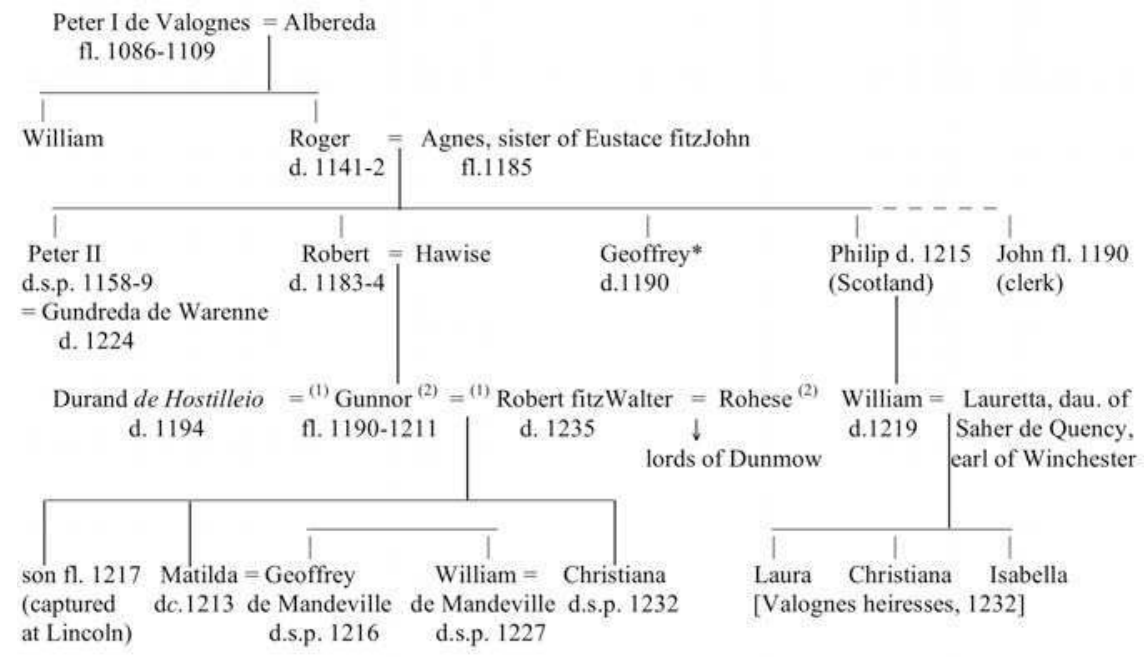

*Geoffrey may have been the youngest son of Roger de Valognes.

117. SANDERS, 1960, p. 12-13, p. 129-130; FARrer, 1923-1925, i, p. 112; Book of Fees, i, 574; Hardy, Rotuli de oblatis, p. 424-425; Rouen, Arch. dép. Seine-Maritime, 20 HP 6; Round, 1900, p. 411. 
Table II: the double kinship of Robert fitzWalter and Richard de Montfichet ${ }^{118}$

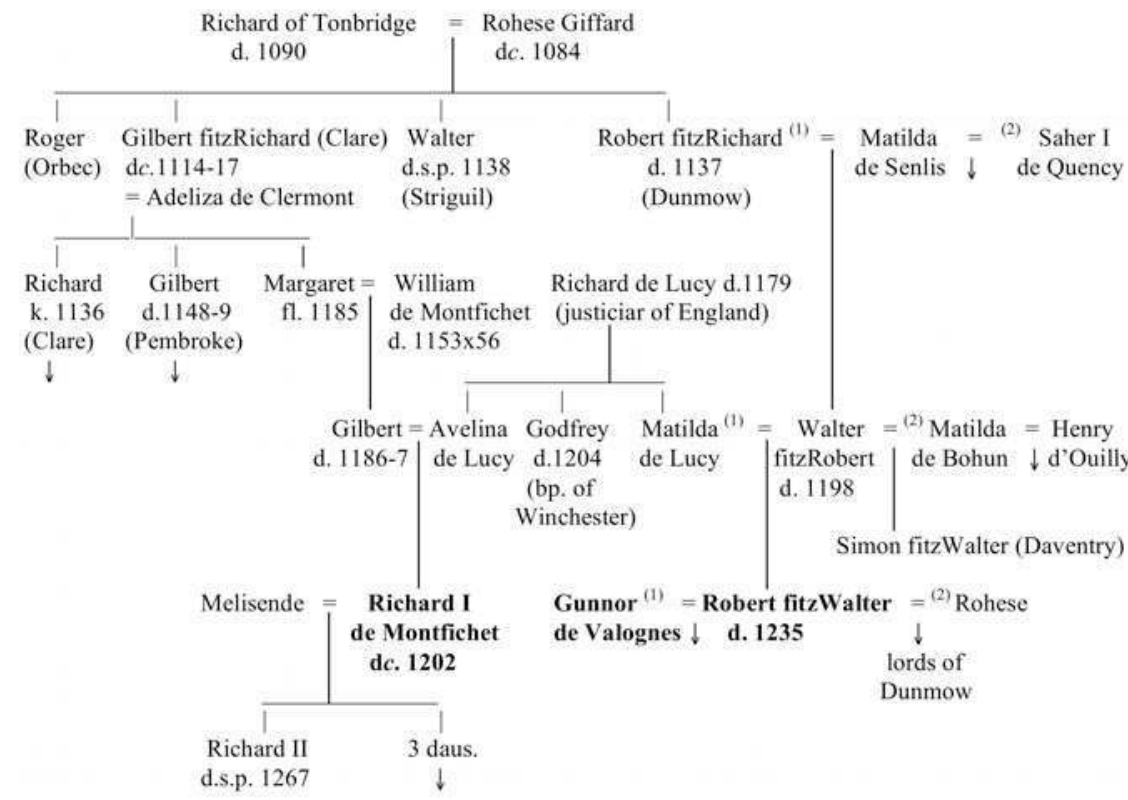

118. Complete Peerage, v, p. 472 (f); Round, 1895, p. 355-363; SANDERs, 196o, p. 129-130; Holt, 1984 and the sources cited there. For the date of the death of Robert fitzRichard, see Regesta Regum Anglo-Normannorum, iii, p. xviii, n. 1. 